\title{
WestVirginiaUniversity
}

THE RESEARCH REPOSITORY @ WVU

Graduate Theses, Dissertations, and Problem Reports

2016

\section{Three Essays on the Heavily Indebted Poor Countries (HIPC) Initiative Debt Relief}

\author{
Minh Tam Tammy Schlosky
}

Follow this and additional works at: https://researchrepository.wvu.edu/etd

\section{Recommended Citation}

Schlosky, Minh Tam Tammy, "Three Essays on the Heavily Indebted Poor Countries (HIPC) Initiative Debt Relief" (2016). Graduate Theses, Dissertations, and Problem Reports. 6583.

https://researchrepository.wvu.edu/etd/6583

This Dissertation is protected by copyright and/or related rights. It has been brought to you by the The Research Repository @ WVU with permission from the rights-holder(s). You are free to use this Dissertation in any way that is permitted by the copyright and related rights legislation that applies to your use. For other uses you must obtain permission from the rights-holder(s) directly, unless additional rights are indicated by a Creative Commons license in the record and/ or on the work itself. This Dissertation has been accepted for inclusion in WVU Graduate Theses, Dissertations, and Problem Reports collection by an authorized administrator of The Research Repository @ WVU.

For more information, please contact researchrepository@mail.wvu.edu. 


\title{
Three Essays on the Heavily Indebted Poor Countries (HIPC) Initiative Debt Relief
}

\author{
Minh Tam Tammy Schlosky \\ Dissertation submitted to the College of Business and Economics \\ at West Virginia University \\ in partial fulfillment of the requirements for the degree of \\ Doctor of Philosophy in \\ Economics \\ Andrew Young, Ph.D., Chair \\ Brian Cushing, Ph.D. \\ Stratford Douglas, Ph.D. \\ Tami Gurley-Calvez, Ph.D. \\ Dongwoo Yoo, Ph.D. \\ Department of Economics \\ Morgantown, West Virginia \\ 2016
}

Keywords: HIPC, debt relief, foreign aid, spatial spillovers, institutional quality

Copyright 2016 Minh Tam Tammy Schlosky 


\begin{abstract}
Three Essays on the Heavily Indebted Poor Countries (HIPC) Initiative Debt Relief
\end{abstract}

Minh Tam Tammy Schlosky

This dissertation consists of three essays that investigates the effect of the Heavily Indebted Poor Countries (HIPC) Initiative. Chapter 1 is the introduction that discuss what my three essays are about. Chapter 2 is my first essay and it tries to answer the question, if there is moral hazards among HIPC member countries while they are finishing the program. Chapter 3 uses empirical data to access if one country's HIPC membership have spatial spillover effects. It uses the Spatial Durbin Model to estimate the effects of HIPC affiliation on neighboring countries. Chapter 4 is a joint effort with Dr. Andrew Young. We use the Economic Freedom index and the Political Rights index to investigate the change in institutional quality of member countries from the time that they enter the HIPC program until the time that they exit. Chapter 5 concludes the paper. 


\section{Acknowledgements}

My life is not possible without my family. I would like to thank my parents, George and Suong Schlosky, for their unwavering support in giving me the best education that they could. They understood the value of human capital and encouraged me to shoot for the moon, getting a Ph.D. Also, I would like to thank my husband, Serkan Karadas, for his ... everything. He stood by me as a patient first year graduate student. He tutored me and helped me passed all of my comprehensive exams. He encouraged me to get to work when I did not have the motivation. He is my one true love of my life and I thank God everyday for blessing me with such a great husband.

Second, I would like to thank Dr. Andrew Young for being my teacher, advisor and dissertation chair. With his guidance, I was able to complete this work. I am very thankful for his advice and patience. I definitely chose the right mentor. I know that I am bit slow, a little socially awkward, and probably frustrated him from time to time, but he was patient and did not give up on me. A big part of my success is due to having him to advise me.

I am also thankful to my dissertation committee members: Dr. Brian Cushing, Dr. Stratford Douglas, Dr. Tami Gurley-Calvez, and Dr. Dongwoo Yoo. I am very happy that I have them to consult with during my years at West Virginia University. Being a TA for Dr. Cushing's Statistics class gave me confidence in the subject and eventually I was able to teach the class by myself. I try to follow his style (cool but hardworking), and hope to be able to become a great teacher like him. Dr. Douglas is my econometrics professor and is someone who I deeply respect. I am thankful for giving me advice on my papers and giving me a mock interview to help me on the job market. Thank you Dr. Tami Gurley-Calvez for teaching me Public Finance and thank you for being a great role model. I hope that one day I can become a great researcher like her. I also would like to thank Dr. Dongwoo Yoo 
for his help on my papers. During both the dissertation proposal and defense, he gave me great comments. Also, if I could have a 6 th member on my committee, I would have ask Dr. Lacombe. Dr. Donald Lacombe is the one who taught me Spatial Econometrics. The skills that I need to work on my second essay. I am very thankful that I took his class, and that he was the teacher. I couldn't ask for a better spatial econometrics teacher. Thank you.

While I am in Morgantown, away from my parents, Dr. Neal Newfield and Dr. Susan Newfield took me under their wings and give me warmth as though I am a part of their family. Every Thanksgiving I was at their house, and Halloween, and Hanukkah/Christmas, and all of the special occasions of the year. They are truly good-hearted people. Even when I moved away, I miss them and think about them often. Another special friend/brother that I would like to thank is Julian Nguyen. Graduate school and life can be stressful and he was a brother who would always be there to listen to me. In Morgantown, Neal, Susan, and Julian are my family. I am grateful for them.

Also, I would like to thank special people who had made a difference in my academic career. Dr. Sandra Trejos, Dr. Gustavo Barboza, Dr. Lynn Smith, Dr. Rod Raehsler, Dr. Paul Woodburne, and Dr. Jerry Belloit. They taught me during my undergraduate years at Clarion University of Pennsylvania. Later I was able to become their colleague for one year while maintaining a visiting position there. They treated me incredibly well and encouraged me to finish my dissertation. Thank you. Especially Dr. Trejos, whose hugs mean so much to me.

Finally, I would like to thank Dr. Christopher Parmeter and Dr. Valerien Pede for helping me with coding in R. Thank you Dr. Parmeter for teaching me how to make reproducible research. He taught me how to use R, and to integrate Latex with R-Studio using Sweave. Dr. Pede's knowledge in spatial econometrics helped me with my second paper. Together, with their help, I am able to work much faster than before. 


\section{Contents}

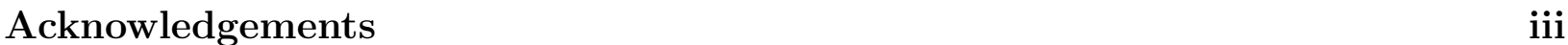

List of Figures $\quad$ vi

List of Tables $\quad$ vii

1 Introduction $\quad 1$

2 Is There Moral Hazard in the Heavily Indebted Poor Countries (HIPC) Initiative Debt Relief Process?

2.1 Introduction . . . . . . . . . . . . . . . . . . . . . 4

2.2 Literature Review . . . . . . . . . . . . . . . . . . . . 8

2.3 A Brief Introduction of the Debt Relief Initiatives . . . . . . . . . . . . . . 11

2.4 Hypothesis Development: Moral Hazard in Debt Relief Programs . . . . . . 13

2.5 Data . . . . . . . . . . . . . . . . . . . . 15

2.5.1 Main Variables . . . . . . . . . . . . . . . . . . . . . 16

2.5.2 Additional Control Variables . . . . . . . . . . . . . . . . . 17

2.6 Econometric Model . . . . . . . . . . . . . . . . . . . . . . . . 19

2.7 Results . . . . . . . . . . . . . . . . . . . 22

2.8 Conclusion . . . . . . . . . . . . . . . . . . . 26

3 Spatial Spillover Effects of Debt Relief from the Heavily Indebted Poor Countries (HIPC) Initiative $\quad 34$

3.1 Introduction . . . . . . . . . . . . . . . . . . . . . 34

3.2 Background on the HIPC Initiative and the MDRI . . . . . . . . . . . 37

3.3 Data . . . . . . . . . . . . . . . . . . . . . . . . . . . . . . . . . . .

3.3.1 Dependent Variable . . . . . . . . . . . . . . . . . . . . . . . . 38

3.3 .2 Explanatory Variables . . . . . . . . . . . . . . . . . . . . . . . . . . . . . . . . . 38

3.3 .3 Control Variables . . . . . . . . . . . . . . . . . . . . . . . . . . . . . . . . . . .

3.4 Econometric Models . . . . . . . . . . . . . . . . . . . . . . . . 40

3.5 Regression Results . . . . . . . . . . . . . . . . . . . . . . . 42

3.6 Conclusion . . . . . . . . . . . . . . . . . . . . . . . 43

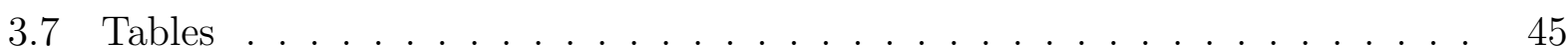


4 Can Foreign Aid Motivate Institutional Reform? $\begin{array}{ll}\text { An Evaluation of the HIPC Initiative } & 56\end{array}$

4.1 Introduction . . . . . . . . . . . . . . . . . . 56

4.2 Foreign Aid and Institutional Quality . . . . . . . . . . . . . . . . . 58

4.3 The HIPC Initiative . . . . . . . . . . . . . . . . . . . . . . . . . . . . . . . . . . . . . . . 61

4.4 The Record thus Far . . . . . . . . . . . . . . . . . . . . . . . 65

4.5 Conclusion . . . . . . . . . . . . . . . . . . . . . . . 69

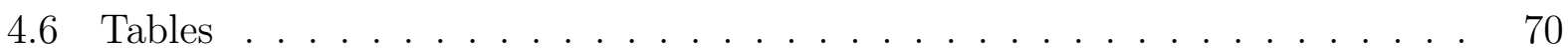

$\begin{array}{lll}5 & \text { Conclusion } & 73\end{array}$ 


\section{List of Figures}

2.1 Illustration of the Debt Laffer Curve. . . . . . . . . . . . . . . . . 9

2.2 Proportional Hazard Test . . . . . . . . . . . . . . . . . . . . . . . . . . 21

2.3 Marginal Effects of Corruption on Interim Duration on different levels of Interim Aid . . . . . . . . . . . . . . . . . . 23

2.4 Marginal Effects of Interim Aid per capita on Interim Duration on different levels of Corruption . . . . . . . . . . . . . . . . . 24

2.5 Kaplan-Meier Survival Function, Interaction Term of Aid and Corruption $\quad 25$ 


\section{List of Tables}

2.1 Variable Description and Sources . . . . . . . . . . . . . . . . 27

2.2 HIPC Decision and Completion Point Dates . . . . . . . . . . . . . . 28

2.3 Countries in the Data Set . . . . . . . . . . . . . . . . . . . . . . . . . . . . . . . . . . . . 39

2.4 Descriptive Statistics . . . . . . . . . . . . . . . . . . . . . . . . . . . . . . . . . . . . . . . 30

2.5 Correlation Matrix . . . . . . . . . . . . . . . . . . . . . 31

2.6 Cox Proportional Hazard: Corruption . . . . . . . . . . . . . . . . . 32

2.7 Cox Proportional Hazard: Rule of Law . . . . . . . . . . . . . . . . . . 33

3.1 Country List $1 \ldots \ldots \ldots$. . . . . . . . . . . . . . . . . . . . . . . . . . . . . . . . . . . 45

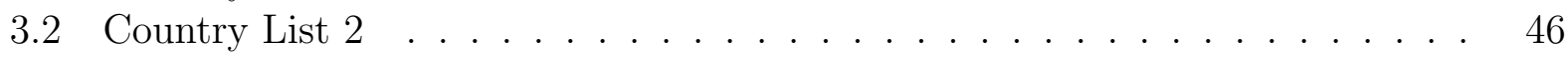

3.3 Descriptive Statistics - 63 countries . . . . . . . . . . . . . . 47

3.4 Descriptive Statistics - 56 countries . . . . . . . . . . . . . . . . . 47

3.5 Correlation Matrix of Main Variables - 63 countries . . . . . . . . . . . . . 48

3.6 Correlation Matrix of Main Variables - 56 countries . . . . . . . . . . . . . 49

3.7 OLS Regression Results: 63 Countries Data Set . . . . . . . . . . . . . 50

3.8 OLS Regression Results: 56 Countries Data Set . . . . . . . . . . . . . . 51

3.9 SLX Regression Results: 63 Countries Data Set . . . . . . . . . . . . . . 52

3.10 SLX Regression Results: 56 Countries Data Set . . . . . . . . . . . . . 53

3.11 SDM Impacts - 63 countries . . . . . . . . . . . . . . . . . . . 54

3.12 SDM Impacts -56 countries . . . . . . . . . . . . . . . . . . 55

4.1 HIPC Initiative Participants: Decision and Completion Dates . . . . . . . . 70

4.2 HIPC Initiative Participants: Changes in Economic Freedom and Political Rights ............................ 71

4.3 Relationship between Aid and Changes in Economic Freedom during Participation in HIPC Initiative . . . . . . . . . . . . . . . . . . . . 


\section{Chapter 1}

\section{Introduction}

As a global effort to increase standardS of living in the world's poorest nations, the eight Millennium Development Goals (MDGs) were set to (1) eradicate extreme poverty and hunger, (2) achieve universal primary education, (3) promote gender equality and empower women, (4) reduce child mortality, (5) improve maternal health, (6) combat HIV/AIDS, malaria and other diseases, (7) ensure environmental sustainability, and (8) develop a global partnership for development. ${ }^{1}$ The Heavily Indebted Poor Countries (HIPC) Initiative works toward those goals along with the Multilateral Debt Relief Initiative (MDRI). They were formed by a joint effort of the World Bank and the International Monetary Fund (IMF). The HIPC Initiative set strict criteria for entering and completing the program. As countries begin the process, they receive interim debt relief. Then, when they finish, they receive a large package of debt relief that can total hundreds of millions or even billions of dollars. My dissertation is composed of three essays that look at the impacts of the HIPC Initiative on its participant countries.

The first essay introduces the idea of moral hazard and investigates the extent to which moral hazard is a problem in the HIPC Initiative. Burnside and Dollar (2000) find that for foreign aid to work, recipient countries need to have high-quality institutions and low inflation. Most HIPC member countries do not meet these conditions. I use the World Bank's measure of corruption to investigate how corruption affects the amount of time that

\footnotetext{
${ }^{1}$ As stated on the United Nation's website: http://www.un.org/millenniumgoals/
} 
passes between a country entering the HIPC Initiative (the decision point) and its successful completion (the completion point). To infer if there is moral hazard, I look at both the amounts of interim aid and corruption levels. Intuitively, interim aid is given to participating countries to help them succeed in implementing structural forms. If, perversely, countries that receive more interim aid, all else equal, are actually slower to implement the reforms, then this suggests a moral hazard problem. In particular, it suggests that participants are more focused on receiving additional interim aid than implementing the reforms. I expect that high levels of corruption will be associated with greater moral hazard. I also anticipate a positive relationship between interim aid and time spent in the HIPC Initiative in the presence of moral hazard. If moral hazard is indeed an important problem in the HIPC Initiative, then the World Bank and the IMF may be spending more money than they need to. In addition to the moral hazard analysis, the first essay also provides a comprehensive study of the factors contributing to the success and failures of the HIPC member countries in completing the HIPC program.

I employ the Cox Proportional Hazard model to perform a duration analysis. Results suggest that interim aid has no effect on the length of the interim period. When a squared term for interim aid is entered into the estimation, it sometimes enters significantly, but the estimated effect is very small. Higher corruption levels are independently and positively associated with the interim duration. However, the interaction term between interim aid and the level of corruption does not have a significant effect on the length of the interim period. I then conclude, that moral hazard does not seem to be an important problem in the HIPC Initiative.

The second essay examines the effects of HIPC Initiative debt relief on economic growth in participant countries and in their neighbors. I employ the Spatial Durbin Model (SDM) to estimate the relationships between economic growth and (i) HIPC Initiative participation, (ii) the amount of debt relief received during participation, and (iii) the amount of time that a participant spends between decision and completion points in the HIPC Initiative. The results indicate that, (i) a country's participation in the HIPC Initiative has at best no 
effect on its real GDP growth; but the estimated indirect effects are actually always negative and often statistically significant. Furthermore, (ii) the sign on the amount of debt relief is statistically significant, indicating that debt relief adversely affects the recipient country's growth, and (iii) the time that a country spends in the interim period negatively affects its GDP per capita.

The final essay a joint effort with Dr. Andrew Young. We examine the effect of participation in the HIPC Initiative on institutional quality. The HIPC Initiative explicitly aims to promote policy and institutional reforms. However, there is a growing literature suggesting that foreign aid (of which HIPC Initiative is a form) has deleterious effects on recipients' institutions. If the HIPC Initiative does not promote (or perhaps even harms) economic growth, (as suggested by Essay 2) then a negative effect of debt relief on institutional quality would be doubly troubling. We examine the relationship between the amount of debt relief received by HIPC Initiative participants and changes in their Economic Freedom of the World and Freedom House Political Rights index scores. In general we find that the promise of the HIPC Initiative to facilitate policy and institutional reforms is largely unfulfilled. A large portion of HIPC Initiative participants experienced no improvements or even decreases in institutional quality from decision to completion. Furthermore, a number of countries experienced backslides in the years subsequent to completing the HIPC Initiative.

In the final chapter, I provide a summary of all results in my three essays and conclude the dissertation. 


\section{Chapter 2}

\section{Is There Moral Hazard in the Heavily Indebted Poor Countries (HIPC) Initiative Debt Relief Process?}

\section{$2.1 \quad$ Introduction}

Foreign aid is a widely researched topic in the economic development literature. It is of great interest to answer questions such as What determines the flow of aid?, Does foreign aid work to achieve its intended goals?, and Are the aid funds misused?, etc. The delivery, utilization, and success of foreign aid are conditional on a large number of factors. For example, donors' intents and recipients' utilization of the funds can be incongruent, and there is some anecdotal evidence to corroborate this claim. Consider the case of Nigeria. In 2006 the President of Nigeria, a large foreign aid recipient, reportedly spent $\$ 1$ million of poverty alleviation funds to sponsor popular music artists Jay-Z and Beyonce to perform at a music festival ${ }^{1}$. Again, in February of 2013, Nigeria spent another $\$ 500,000$ inviting tabloid celebrity Kim Kardashian to co-host an event called Love Like A Movie. Clearly, such events do not help the poor or reduce hunger, which are among the main objectives of foreign aid. However such events highlight the need for further studies on understanding when and how foreign aid works. The misuse of funds suggest that there could be a mismatch between

\footnotetext{
${ }^{1}$ In 2006, Nigeria received more than $\$ 13$ billion U.S. in net official development assistance (World Bank)
} 
foreign aid donors' intent and the recipients' use of foreign aid.

In this essay I focus on debt relief as a form of foreign aid and investigate the factors contributing to its success. According to Cassimon and van Campenhout (2007), debt relief is a type of multilateral aid that outperforms other modes of aid delivery. They use a panel vector autoregressive model and find that, in the long run, HIPC debt relief helps reduce future loans. They also find that it increases government revenue collection. To make the debt relief more effective, the IMF and the World Bank created two debt relief programs to help countries that have exceedingly high levels of debt. These programs are the Heavily Indebted Poor Countries (HIPC) initiative and the Multilateral Debt Relief Initiative (MDRI). The IMF and World Bank monitor countries that participate in these programs. Participants are required to submit reports on their macroeconomic conditions and their spending on poverty reduction programs. By the end of 2010, the HIPC initiative and the MDRI provided $\$ 76$ billion and $\$ 38$ billion, respectively, in debt relief in the end-2010 present value (PV) terms. In this study, I address two issues with respect to the HIPC initiative's debt relief efforts. I attempt to infer whether the HIPC initiative suffers from moral hazard problem and I seek to identify the determinants of the length of the time that it takes a country to successfully complete the HIPC initiative's program.

The HIPC initiative involves two stages: the decision point and the completion point. The time it takes for a country to pass from the decision point into the completion point is called the interim period. The average interim period for a country participating in the HIPC initiative is approximately 45 months. However, there is a wide variation in the length of the interim period across countries. It is not well-understood why it takes so little time for some countries to complete the HIPC initiative while it takes so long for others. For example, the time it took for Uganda to reach the completion point was only 3 months, and Bolivia took 16 months; alternatively, the Democratic Republic of Congo did not complete the HIPC initiative for 84 months and, Guinea-Bissau took even longer (120 months). Is there any special reason why these 36 HIPC countries have large differences in interim durations? 
In this paper, I also investigate potential moral hazard problems associated with the HIPC initiative. In this context, the multilateral donors (organized under the auspices of the World Bank and IMF) are the principals while the HIPC initiative participants are agents. The principals not only want to lower the debt burden of these members but they also aim to make that outcome sustainable by insisting on structural reforms to participants' policies and institutions. The principals desire that interim (i.e., during participation in the HIPC initiative) debt relief be used to promote such reforms. However, the agents may not desire such reforms (though certainly desiring ultimate forgiveness of their debts!) and, instead, desire to use the interim funds for other purposes. Indeed, to the extent that the donors have an ultimate interest in reforms, the agents may have an incentive to delay reforms in a way that interim aid is provided for a longer period of time; accumulating in a larger total amount. This study addresses the moral hazard issue in the debt relief process by investigating whether a country stays in the interim period due to structural reasons or just to receive more immediate interim relief. Each year, as a country remains in the interim period, it receives interim aid with the expectation that it will speed up the process of completing the final requirements to reach the completion point. The longer a country delays reforms, the longer it stays in the interim period and ultimately receives more cumulative interim aid. Moral hazard occurs when a country stays in the interim period longer to maximize its interim aid, even though this cumulative amount is subtracted from the final sum payment at the completion point.

I use survival time analysis to document the factors impacting the interim period in the HIPC debt relief process and to assess the presence of moral hazard. The duration, measured in months, starts at the time a country reaches the decision point and ends when it reaches the completion point. By employing a rich set of explanatory variables, I find that higher HIPC interim aid, more control of corruption, better rule of law, and higher per capita official development aid (ODA) shorten the interim period for a country. On the other hand, a higher inflation rate and an initial GDP per capita exceeding $\$ 1,000$ are associated with longer interim period. Overall, the interim aid, macroeconomic factors, and institutional 
quality play a significant role in the completion of the HIPC program.

In answering whether there is a moral hazard in the HIPC debt relief process, I use control of corruption, amount of interim aid, and macroeconomic progress to identify situations under which moral hazard is likely to occur. I use macroeconomic indicators such as GDP per capita growth, inflation rate, trade level, and net ODA per capita as control variables because they can impact a country's standard of living. In my paper, moral hazard is not directly observed. Since I cannot observe the decision to intentionally stay longer in the interim period, I argue that countries that receive higher level of interim aid (but still remain in the interim period) and have poor control of corruption are more likely to commit moral hazard. I infer the presence of moral hazard if higher amount of interim aid in corrupt countries is associated with longer interim period. Therefore, I use the interaction between interim debt relief and the institutional quality variable as the proxy for moral hazard.

This paper contributes to the literature the following ways. First, to the best of my knowledge, it is the first study documenting the underlying factors contributing to the success of the HIPC debt relief effort. Given the size of these debt relief programs, it is critical to understand why some countries succeed and why some fail. The results in this study offer a guide to policing the debt relief process more effectively. Second, this paper sheds light on the moral hazard issue in the debt relief process. Third, it incorporates a duration modeling methodology from health economics and thus offers new tools for evaluating the different dimensions of the debt relief efforts.

The rest of this paper proceeds as follows. Section 2.2 provides a literature review on why some countries are poor, and it compares traditional debt relief and the HIPC initiative. This section also contains a discussion of debt overhang, the debt Laffer curve, the geography of the HIPCs, and the importance of institutions in the HIPCs. This literature review highlights the need for the initiatives such as the HIPC and the MDRI. Section 2.3 discusses the HIPC and MDRI processes by emphasizing all of the requirements a country must meet in order to pass each point. Section 2.4 outlines the moral hazard issue in the debt relief process. 
Section 2.5 introduces and describes the data. Section 2.6 outlines the empirical model, and Section 2.7 discusses the results. Section 2.8 concludes the paper and provides policy implications.

\section{$2.2 \quad$ Literature Review}

The HIPC initiative was established with the goal of helping its member countries get out of unsustainable debt levels. So far, there is mixed evidence on the Initiative's success. Dagdeviren and Weeks (2001) report that the full debt cancellation has only a small impact on reducing poverty in the HIPC initiative participants, but they also argue that the formation of the HIPC initiative is a step in the right direction to foster sustainable growth. Nwachukwu (2008) finds that HIPC debt reliefs' impact is only marginal and that the countries will not be able to meet the Millennium Development Goals by 2015. Fonchamnyo (2009) examines the HIPCs that had completed the program and finds that on average, they had improved in terms of education and investment. However, those improvements may not be sufficient for meeting the Millennium Development Goals.

Having a high debt level can slow down economic growth and thus make it difficult for countries with heavy debt burden to reach the Millennium Development Goals. Excess external debt accumulation can cause problems such as large debt overhang (Krugman 1988, Sachs 1989, Dooley 1989, and Borzenstein 1990). A country with debt overhang is, as described by Krugman (1988), "a country that has the expected present value of potential future resource transfers is less than its debt." He argues that excessive debt overhang distorts the value of external debt and discourages new investments. Cohen (1997) and Elbadawi et al. (1996) find that debt overhang causes weak economic performance. Sachs (2002) suggests that debt overhang can cause poor countries to fall into a poverty trap. With debtors in a poverty trap, creditors are unlikely to get repaid. Hence, for a better chance of getting part of their money back, creditors forgive some debt so that the debtor countries do not slide over to the wrong side of the debt Laffer curve. 
Figure 2.1: Illustration of the Debt Laffer Curve.

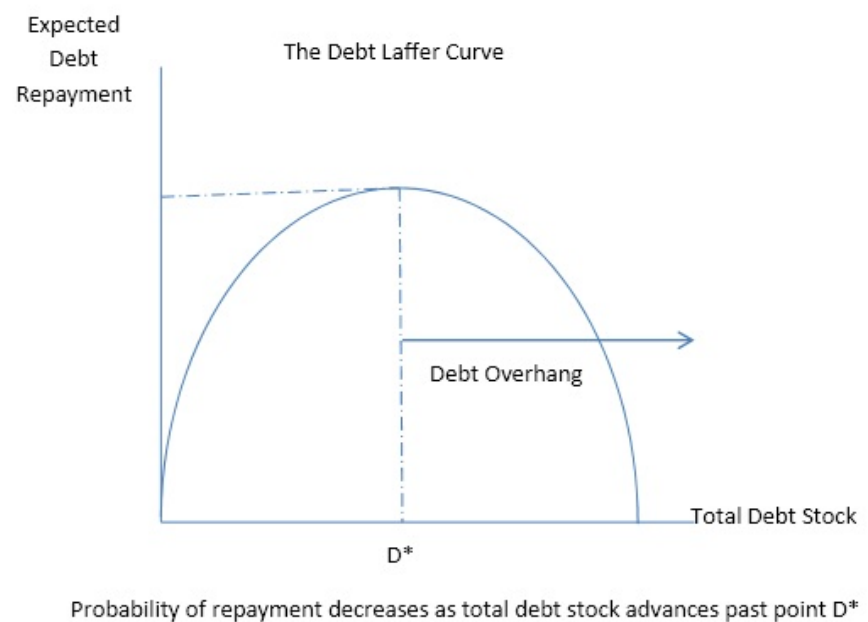

As I show in Figure 2.1, the debt Laffer curve illustrates the debt overhang problem. To a certain point (let that point be $\mathrm{D}^{*}$ ), funds borrowed can be repaid. However, after point D*, the probability of default increases. Kumar and Woo (2010) study a panel of 38 countries from 1970 to 2007 and find an inverse relationship between initial public debt and long-run growth. Koeda (2008) finds that there is an important link between a country's initial economic condition and the effectiveness of debt relief, near the threshold of having debt overhang. She provides empirical evidence for growth stagnation near this threshold area. Cecchetti, Mohanty, and Zampolli (2011) study a panel of 18 countries from 1980 to 2010 and find that economic growth starts to decline when countries reach the threshold level of $85 \%$ of GDP. The Enhanced HIPC initiative sets the debt to export ratio at $150 \%$, which is well beyond this threshold of $85 \%$.

Claessens (1990) uses the debt Laffer curve to argue that across the board debt cancellations will not be beneficial to creditors. Debt forgiveness only helps the countries whose debt stocks are on the right side of $\mathrm{D}^{*}$. Hence, canceling those debts for the countries with D less than $D^{*}$ will not help creditors. Therefore, it makes sense for the HIPC initiative to place a ratio of debt to exports as a requirement for qualification. The HIPC condition of debt unsustainability is that the debt to exports ratio must be greater than $150 \%$. Based on this requirement, I include the debt to export criteria greater than 1.5 as one of the indicator 
variables in this study.

On the moral hazard side, Jeanne et al. (2001) argue that financial safety nets create moral hazard. They also claim that the cost of international bailouts are not high for the international community. They suggest that the size of the bailouts should be conditional on government policies. Ndikumana (2004) presents evidence that countries that received more aid also received more debt relief compared to those that did not qualify for debt relief. This leads to the idea that international foreign aid provides incentives for moral hazard to its recipient countries such that these countries borrow more with the expectation of being forgiven later.

Isopi and Mattesini (2010) look at the issue of monitoring; they find that donors give aid without assessing previous performance and continually give more aid without verifying those results. The lack of a perfect monitoring system in place can be a breeding ground for moral hazard. Amegashie et al. (2007) propose the use of tied aid as a method of reducing moral hazard. In summary, foreign assistance can be ineffective if the recipient country either lacks the appropriate level of rule of law or if a monitoring system is not put in place. As a way to address these concerns, the HIPC initiative follows the status of recipient countries' macroeconomic conditions and gives assistance only to those that improved.

To have any meaningful improvements, good institutions are necessary (North, 1990), because they provide the structure that would reduce transaction costs necessary for exchanges. Burnside and Dollar (2000) document that aid is only effective if a country has a low budget deficit and low inflation, and it is open to trade. However, the countries that could qualify for HIPC assistance do not have low inflation. This may contribute to longer interim period. Werlin (2005) argues that it is not possible to help poor countries if they do not have a good government. Easterly (2002) studies the countries with high debt stocks and finds that despite repeated deliveries of external aid, those countries continually needed more help. He argues that these results are due to the irresponsibility of the recipient countries' governments. They keep on borrowing because they did not feel threatened from the 
consequences of not performing adequate reforms. Alesina and Weder (2002) find that aid is not given conditional on governance quality. Actually, more corrupt governments get more aid.

Knack (2000) documents that aid dependent countries, such as HIPCs, have low institutional quality. Brautigam (2004) and Brautigam and Knack (2004) conclude that high level of foreign aid can deteriorate the quality of governance by increasing incentives for corrupt activities. In this study, following the key findings in the literature, I include institutional variables such as the Control of Corruption index, the Rule of Law index, and the legal origin of each country in my specifications.

\subsection{A Brief Introduction of the Debt Relief Initiatives}

The main debt relief initiatives discussed in this paper are the Heavily Indebted Poor Countries (HIPC) initiative and the Multilateral Debt Relief Initiative (MDRI). The HIPC initiative was launched in 1996 by the International Monetary Fund (IMF) and the World Bank. The MDRI was launched in 2006 with the goal of providing additional support to countries participating in the HIPC initiative. Both the HIPC Initiative and the MDRI provide debt relief to assist countries towards attainment of the Millennium Development Goals (MDGs).

The HIPC initiative calls for the voluntary provision of debt relief by the creditors, who can be multilateral, bilateral, or commercial. In 1999, to help more countries qualify into the program, an enhanced HIPC initiative was formed. The enhanced HIPC initiative lowered the qualification criteria. For example, the debt-to-exports ratio is now 1.5 instead of 2.0 and the debt-to-fiscal revenue percent is $250 \%$ instead of $280 \%$. These downward adjustments helped more countries become eligible to seek debt relief via the HIPC initiative. A 2003 evaluation by the World Bank and the IMF finds that the initiative greatly reduced the debt burden of qualified HIPCs. ${ }^{2}$

\footnotetext{
${ }^{2}$ http://www.imf.org/external/pubs/ft/exrp/debt/eng/
} 
The HIPC initiative debt relief differs from normal official development aid in that the former places numerous criteria for candidate countries to qualify for the HIPC program. Candidate countries must satisfy a certain level of indebtedness to enter the program and must demonstrate a firm commitment to reforms before they pass from the decision point into the completion point. For example, requirements that Togo had to fulfill to reach the completion point included developing a mechanism to track public expenditures, appointing judges to the Court of Accounts, and publishing reports auditing government's expenditures and revenues. ${ }^{3}$ Bolivia passed the decision point by implementing custom reforms, approving a new tax procedures code, and creating a single treasury account with enhanced transparency and expenditure control. ${ }^{4}$ By the end of 2011, 32 countries reached the completion point and four countries achieved the decision point. I provide a complete list of countries and their date of admittance to the HIPC program in Table 4.1.

The HIPC initiative funding process is divided into two stages: Decision and completion point. To potentially be eligible for HIPC initiative debt relief, a country must satisfy the following conditions: (1) it is International Development Association-only (IDA) and Poverty Reduction and Growth Facility-eligible (PRGF), (2) the debt burden by end-December 2004 must be above the threshold of $150 \%$ for the present value of debt to exports of goods and services ratio, and $250 \%$ for the ratio of present value of debt to fiscal revenue. For (1), the countries must be the ones that are eligible for loans from the IDA and for the Enhanced Structural Adjustment Facility. This means that, if left on their own, they will not be able to get to a sustainable debt level. For (2), the country must have the ratio of exports of goods and services to GDP, and the ratio of fiscal revenue to GDP above $30 \%$ and 15\%, respectively. In addition to these two requirements, the country must begin a reform program supported by the IMF and IDA. After passing this stage, the country reaches the decision point.

\footnotetext{
${ }^{3}$ Togo's IMF completion point document. January 2011.

${ }^{4}$ Bolivia's completion point document, 2001.
} 
The completion point entry is determined by the Executive Board of IDA and IMF. To pass, a country must have (a) debt burden indicators above the HIPC threshold for the year prior, (b) established a satisfactory track record of policy performance under the IMF and IDA supported programs, and (c) put together a Poverty Reduction Strategy Paper (PRSP). ${ }^{5}$ The PRSP is the document that lays out the actions that countries will take to reduce poverty and implement policy reform. It is developed based on each country's specific situation. The HIPC participants must have their strategies endorsed by the IMF and the World Bank board. If a country satisfies all of these conditions, it will receive irrevocable debt relief. It is eligible for $100 \%$ debt relief owed to the AfDB, IDA, and the IMF under the MDRI.

\subsection{Hypothesis Development: Moral Hazard in Debt Relief Programs}

In order to qualify as a HIPC recipient, a country must show signs of improvement. Moral hazard is present when the incentives to receive the debt relief overcome the incentives to reform. Once a country gets past the HIPC decision point then it may have an incentive to try and remain in the interim period longer to maximize the amount of interim debt relief that it receives. A HIPC initiative participant receives interim aid to help them get into successfully reach the completion point. The interim aid is based on the participant demonstrating (through its own reports) the achievement of certain macroeconomic and structural outcomes. Participants, therefore, may have an incentive to manipulate the process such that they continue to receive interim aid disbursements while actually prolonging the time until the ultimate completion.

Incentives for moral hazard can arise from the receipt of interim relief. However, there are actually two ways moral hazard can happen: from the provision of (1) interim assistance

\footnotetext{
${ }^{5}$ Poverty Reduction Strategy Paper, and it can be in the form of an Interim PRSP, PRSP preparation status report, full-PRSP, or PRSP-Annual Progress Report.
} 
and (2) topping up aid. ${ }^{6}$ For (1) when a HIPC participant stays longer in the interim period, it receives more interim aid cumulatively. For (2), longer interim duration can change the amount of aid needed by the HIPC member due to extraordinary circumstances that arise. The HIPC initiative agrees on the amount of the debt relief package at the decision point. However, on its path to complete the HIPC program, if unforeseen circumstances cause a country to need more aid, the HIPC initiative will give "topping up" aid. Hence, by lengthening the interim period, opportunities to receive topping up aid increases. Due to data limitations, I will only be focusing on the interim aid in this paper.

At the decision point, countries are assessed, and debt reliefs are provided on a case by case basis. The Executive Board determines the aid flowing to each country, in millions of US dollars. These payouts are high; however, the countries can receive more interim aid by improving gradually while preparing the PRSP to qualify for the completion point. That will maximize their cumulative interim aid amount. At the completion point, all of $100 \%$ of their debt prior to 2004 will be irrevocably forgiven.

I do not have a direct measure of moral hazard. Researchers across different fields tackle this problem by identifying the situations under which moral hazard is most likely to occur. In the context of the HIPC initiative participants, moral hazard occurs when countries stay intentionally longer in the interim period to maximize their interim aid. To determine whether there is moral hazard, I use both the interim debt relief amount and the control of corruption index by Kaufmann et al. (2010). The control of corruption index identifies countries with lax controls of corruption. This index captures how the ruling class is perceived to use their political power to extract private gains for themselves. In this regard, a higher corruption level in a recipient country may be the reason its duration in the interim period is longer. Poor governance may lead to the country not being able to fulfill the HIPC completion requirement. Furthermore, poor governance can lead to the stretching of the interim period for more interim aid because the money went somewhere else instead of gearing towards poverty reduction and policy reforms.

\footnotetext{
${ }^{6}$ Ethiopia, Sao Tome and Principe, and Niger received topping up aid from the HIPC initiative
} 
For a given HIPC initiative participant, we can argue for the presence of moral hazard if (1) high corruption leads to longer interim period and (2) the interim aid received has no effect on, or lengthens, the interim duration, after controlling for macroeconomic factors and conflict. For (1) it is obvious that high corruption can thwart policy reform thus lengthening the interim period. For (2) the interim aid that is meant to shorten the interim duration fail to accomplish that goal. I will conclude that there is possible moral hazard if both of these two conditions hold, even when I control for macroeconomic circumstances such as high inflation, or the presence of conflict. That means the longer interim period is not the result of macroeconomic hardship but something else, and that something else may be moral hazard. To infer the presence of moral hazard, I focus on the interaction term between interim debt relief and corruption (or low rule of law). If the interaction term points to a longer interim period, I interpret it as evidence for moral hazard.

\subsection{Data}

As of December 2010, there were 36 HIPC countries, 32 passed and four were still in the interim period. Due to some missing information, the multivariate analysis that I perform will only include 33 countries. The countries that I omit are Afghanistan, Benin, and Sao Tome Principe. The dependent variable in this study is the length of the interim period, timemo, which I measure in months as the distance between the decision point and the completion point. Because my explanatory variables include time varying covariates, I need to break each country into separate observations. I calculate each country's individual cumulative months, timemo, by taking the difference between the end year $t$ with its date of entry into the program. For example, Ethiopia entered the initiative in November of 2001 and completed in April of 2004, then for the year 2001 the timemo is 2 (November and December), for the year 2002 it is 14 , for 2003, it is 26 , and for 2004, it is 30 .

The right hand side include the main explanatory variables interim debt relief, institutional quality (policy) variables, interactions between debt relief and policy, and other 
control variables. The main explanatory variables are the interim HIPC debt relief amount per capita and the institutional quality variables such as the Control of Corruption index, and the Rule of Law index. I multiplied the Control of Corruption index and the Rule of Law index by negative one, so that instead of measuring less corruption, it now measures more corruption, and instead of better rule of law, now higher numbers indicate lower rule of law. Overall, countries with lower governance quality will have lower policy index.

I incorporate additional control variables to account for factors such as macroeconomic status and geography. Macroeconomic status variables include the inflation rate, the debt service to GNI ratio, the initial GDP per capita value, net official development aid (per capita), openness to trade, real GDP per capita growth, and the revised Polity score measure. The geographic characteristics control variable group incorporates indicator variables to reflect if a country is in the African continent, or if it is high in terms of absolute latitude. Remaining control variables are the indicator variables "conflict" and "Original HIPC". A summary of all variable descriptions and sources are listed in Table 2.1.

\subsubsection{Main Variables}

The World Bank and the IMF provide yearly "Status of Implementation" reports on the HIPC initiative and the MDRI that include yearly debt relief amounts to each recipient country. The amount of debt relief, in millions of US dollars, are provided by these HIPC initiative and MDRI reports. The report also lists the dates that each country is admitted to the decision point stage, and when they reach the completion point. The duration passed between the decision point and the completion point is called the interim period, and it is calculated in months. This variable "timemo" is duration data that has a non-normal distribution; hence, linear regressions cannot be used. Overall, the main explanatory variables in this study are: (1) the interim amount of debt relief that each country receives, (2) the policy variable (corruption or rule of law).

The institutional quality variables I use to test for the presence of moral hazard are the 
Control of Corruption index and the Rule of Law index. I employ these variables to estimate the effect of institutions on the likelihood of a country's success in the HIPC initiative process. Kaufmann, Kraay, and Mastruzzi (2009) estimate these variables in a World Bank study. According to Kaufmann, Kraay, and Mastruzzi (2009), Control of Corruption measures how prevalent the public perceives the use of official power for enhancing private gains. The Rule of Law index is a measure of the quality of contract enforcement, property rights, the police, the courts, and the possibility of crime and violence. These variables are multiplied by -1 to give them the opposite meaning, so that when I control for the interaction terms (interim aid * institutional quality), they will be easier to interpret. A low "control of corruption", after multiply by -1 , will mean higher "corruption" (lack of control). Therefore, in my data set, a high value for the "corrupt" variable means higher corruption.

\subsubsection{Additional Control Variables}

I need to separate the effects of net official development aid (ODA) from HIPC interim debt relief. Since yearly interim aid is not the single source of financial assistance that HIPC participants receive, I also include their net official development aid in the analysis. Net official development aid (ODA) exceeds interim HIPC debt relief by far each year. The mean net ODA these countries receive is $\$ 74.137$ millions per year.

The current macroeconomic status of a country in the HIPC program will affect its ability to exit the interim period. The HIPC initiative requires improvements in macroeconomic performance and structural reforms on the part of participants. I expect that a country spending most of its revenue on repaying accumulated debt will not have the resources to put into implementing its PRSP. Therefore, I create a new variable called debttogni to control for debt service as a proportion of national output. I also control for income by including the real GDP per capita growth. I control for the openness of a country by including the Openness to Trade variable from Heston, Summers, and Aten (2012). It is calculated by totaling exports and imports then dividing it by the real GDP per capita, in constant prices. 
For the democracy measure, I use the Combined Polity score from the Polity IV Project Data set from Marshall and Jaggers (2011). The combined polity score shows how autocratic or democratic a country is. The measure ranges from +10 , which is strongly democratic, to -10 , which is strongly autocratic. It is essential to include this control variable because a more autocratic government will be able to move resources more quickly, or restructure government expenditure patterns better to accomplish their goals and pass to the completion point. However, autocratic regimes will also be more susceptible to corruption.

A country in conflict will be less likely to exit the HIPC program because of social unrest. I use the Uppsala Conflict Data Program's Department of Peace and Conflict Research data set to separate out countries experiencing a conflict during year $t$. The conflict variable equals 1 for a country in conflict and 0 otherwise.

I control for the starting status of the HIPC countries by using the initial value of their real GDP per capita. I expect that a country started out in an inferior position would need more time to complete the interim requirements. This is a level measurement, not a categorical dummy variable.

Also, I control for countries starting the HIPC process before the Enhanced HIPC initiative relaxed its criteria. The variable 'original' captures the advantage that a country gets from entering the initiative early. These original countries re-entered the new initiative, (i.e, the Enhanced HIPC initiative,) at the decision point, and some of their previous accomplishments may help them reach the completion point faster. The ten original HIPCs are Benin, Bolivia, Burkina Faso, Honduras, Mali, Mauritania, Mozambique, Senegal, Tanzania, and Uganda.

Following Gallup, Sachs, and Mellinger (1999), I include geographic characteristics of the HIPC countries. I select two indicator variables to control for differences in their geography: absolute latitude and African continent. The African variable takes a value of 1 if it is located in the African continent and 0 otherwise. Furthermore, African countries get additional debt 
relief from the African Development Bank; hence, I insert a dummy variable for a country being in the African continent. Also, I use the absolute latitude measure by La Porta, Lopez-de-Silanes, Shleifer, and Vishney (1999), who use the capital city as a reference point. The values for this measure range between zero and one. The lower the value, the closer the country is to the equator. According to Gallup, Sachs, and Mellinger (1999), countries closer to the tropics experience harder times in economic development.

\subsection{Econometric Model}

I use the semi-parametric Cox proportional hazard model, a type of duration analysis. Duration models are useful for measuring the risk of an event happening, and for this paper, reaching the completion point is the event. The time that it takes for a country to go from the decision point to the completion point is the dependent variable in this study is the interim duration in months, timemo. The advantages of hazard models are their ability to deal with censored data and that they produce hazard rates. I have right censored data with 4 out of the 36 countries not having an end spell. The ending result of the analysis gives me an understanding of which determinants cause longer interim durations.

Survival time models are usually used in medical studies that examine various factors affecting a person's chance of survival over a period time. Probability of dying is the failure rate, and the failure to survive results in death. Survival time models are designed for the analysis of time duration data, and they help with this study thanks to their ability to measure the probability of a determinant causing a country to travel from one state to the other, namely in or out of the interim period. Therefore, the event is reaching completion point and the duration is measured as months spent in the interim period.

Studies that have used duration models include Douglas (1998), Bruce, Barbour, and Thacker (2004). Douglas (1998) uses this duration analysis to investigate the determinants of cigarette smoking. Bruce, Barbour, and Thacker (2004) use a duration model to find determinants that affect the welfare reentry rates. They find that black, single, or less edu- 
cated individuals are more likely to return to welfare after they exited the program (shorter off-welfare durations). Studies using specifically the Cox proportional hazard model include Ragusa (2010), Kluver and Sagarzazu (2013), and Fogarty, Jalalzai, Hankinson (2013). Ragusa (2010) uses the Cox proportional hazard model to conduct an event history analysis on the lifecycle of public policy. The duration is from the time an existing legislation is repealed to the time that is enacted (the event). He finds that the three determinants that affect the policy life are a divided party control, previous repeals, and political polarization. Kluver and Sagarzazu (2013) used the Cox model to study decision-making speed by the European Union legislative bodies. They find that ideological distance lengthens the duration of policy making across proposals. Fogarty, Jalalzai, and Hankinson (2013) use the Cox model to study the duration of a widow's career in the United States House of Representative after their husbands have passed away. Using the hazard rates, they find that the determinants that matter are age, region, and majority/minority margins.

In my paper, the survival time function, $S(t)$, estimates effects of various variables on the probability of a country exiting the interim period in a point in time, given that it has not exited yet. Here, $t$ is the current time, and $T$ is the ending time, which is the year at which a country enters the completion point. $X$ is a vector of explanatory variables that include all control variables. Some explanatory variables are time dependent, which means they change with time. Therefore, they are time-varying. My data is right censored, which means that a few countries did not get to the completion point.

Using Cox model, I can make full use of all of my countries by splitting the countries into many observations; one observation for each year. To adapt time-varying covariates, I split countries up. For example, Burundi entered the decision point August of 2005. At the end of the year 2005, Burundi's interim period is 5 months (August, September, October, November, December), it receives a 0 in the dummy variable complete for not having completed the program. It had certain macroeconomic conditions, and it received some amount of interim aid and net ODA that year. Next year, Burundi receives a 17 for the interim period (5 from the year 2005 and another 12 months for the year 2006), and it had a different 
set of numbers for macroeconomic variables and aid amounts. By the time that Burundi completed the process in 2009, it receives a 1 for complete, and that signifies that it exits the program. For the year 2009, Burundi get a new set of macroeconomic and aid measures. Hence, even though Burundi is only one country, it corresponds to five different observations (one for each year: 2005, 2006, 2007, 2008, and 2009) in the data set.

There are two options when using survival time model. The first one is proportional hazard, and the second one is accelerated failure time model. The accelerated failure time model assumes that the hazard will accelerate or decelerate. The proportional hazard model assumes that the baseline hazard rate is the same for all countries, but can vary with time. To indicate whether a proportional hazard or an accelerated failure time survival model should be used, I run proportional hazard tests for all model specifications. The results show no evidence against the assumption of proportionality of hazards. Therefore, I choose to use the Cox proportional hazard model. Figure 2.2 shows the plot of the Schoenfeld residuals versus $\log ($ time). When the Beta(t) curve does not deviate far from the zero line, we have proportional hazard.

The Cox model is characterized by a hazard and a survival function.

Hazard function: $\mathrm{h}(\mathrm{t})=h_{o}(t)^{\exp (X \beta)}$

Survival function: $\mathrm{S}(\mathrm{t})=S_{o}(t)^{\exp (X \beta)}$

The survival time study use hazard rates as an output. The hazard rate depends on the conditional probability of exiting the interim period at a given time. In other words, the hazard function, $h(t)$, is the instantaneous failure rate. Given that country $i$ has not exited the interim period, the probability that it would happen the next period is $P(t \leq$ $T \leq t+\Delta-t \geq T)$. The failure function is $F(t)=P(T \leq t)$. The probability of surviving is its complement, 1 minus the failure rate $S(t)=P(T>t)=1-F(t)$.

I convert my results to coefficients instead of hazard probabilities for ease of interpretation. The Cox proportional hazard model coefficients are explained by their signs. Negative 
Figure 2.2: Proportional Hazard Test

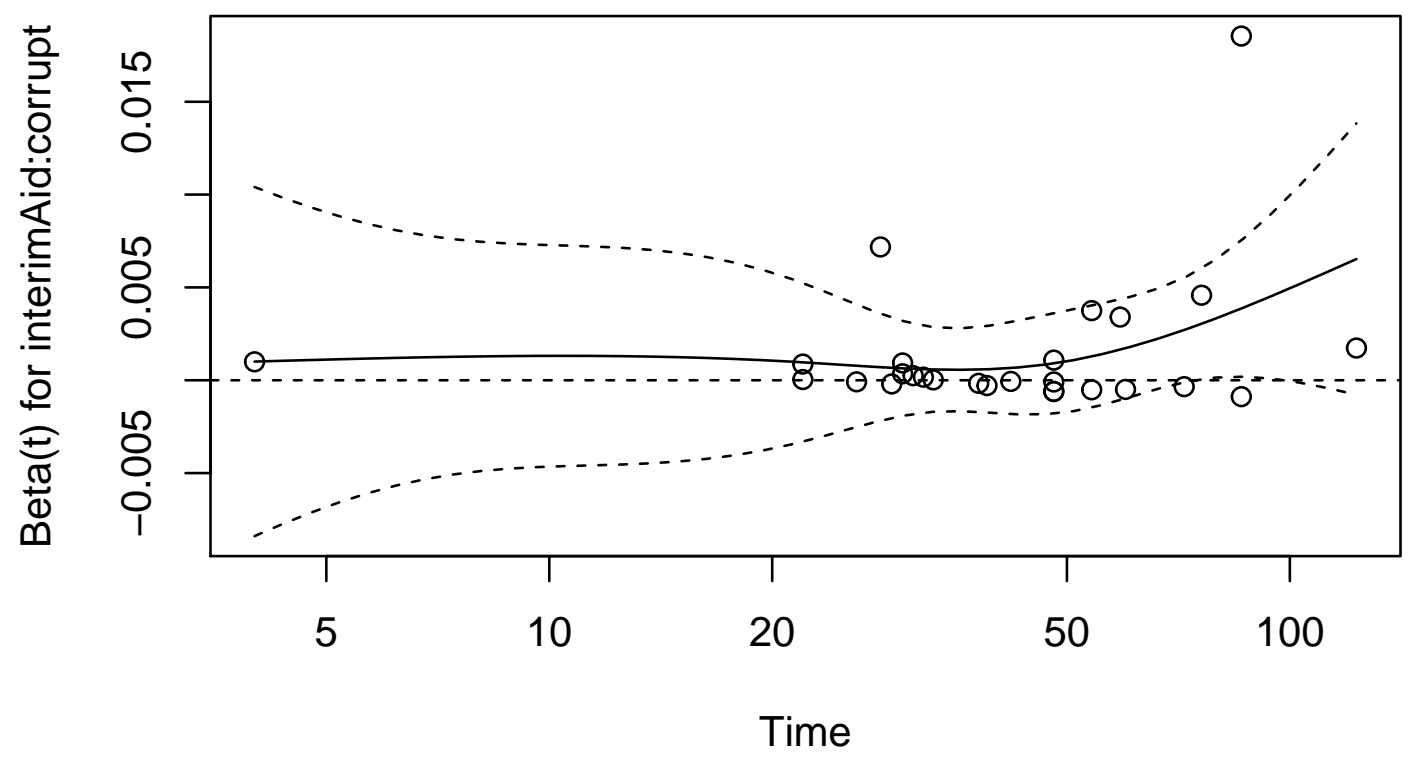

coefficients indicate increased survival time; hence, increased interim period. Positive coefficients means decreased survival time and lessened duration.

\section{$2.7 \quad$ Results}

I provide regression results for the survival time analyses in Table 2.6 and Table 2.7. Although, the models differ in policy variables; they produce consistent outcomes: covariates that produce positive coefficients are the amount of interim aid in billions, net ODA in billions, interim aid in billions squared, and the dummy variable Original. In a proportional hazard model, we look at the increased or decreased hazards. A higher hazard gives a positive coefficient, which indicates shorter duration. Hence, positive coefficient variables are helping the countries speed up to the completion point. Covariates that have negative coefficients are the policy variables (corruption and low rule of law), interaction variables between interim aid and policy, interaction between interim aid squared and policy, higher debt service to GNI ratio, being more open to trade, and in some instances, being located in 
the African continent. These variables contribute to the lengthening of the duration period.

When a model include interaction variables, we need to interpret them according to their marginal effects. When we have $y=\beta_{o}+\beta_{1} x_{1}+\beta_{2} x_{2}+\beta_{3} x_{1} x_{2}+\varepsilon$, the marginal effect of $x_{1}$ is $\beta_{1}+\beta_{2} x_{2} \cdot{ }^{7}$ I show their marginal effects in Figure 2.3 for corruption and Figure 2.4 for InterimAid. In the figure, the solid lines represent the marginal effect while the dashed lines shows their $95 \%$ confidence intervals.

Figure 2.3: Marginal Effects of Corruption on Interim Duration on different levels of Interim Aid

\section{Corruption}

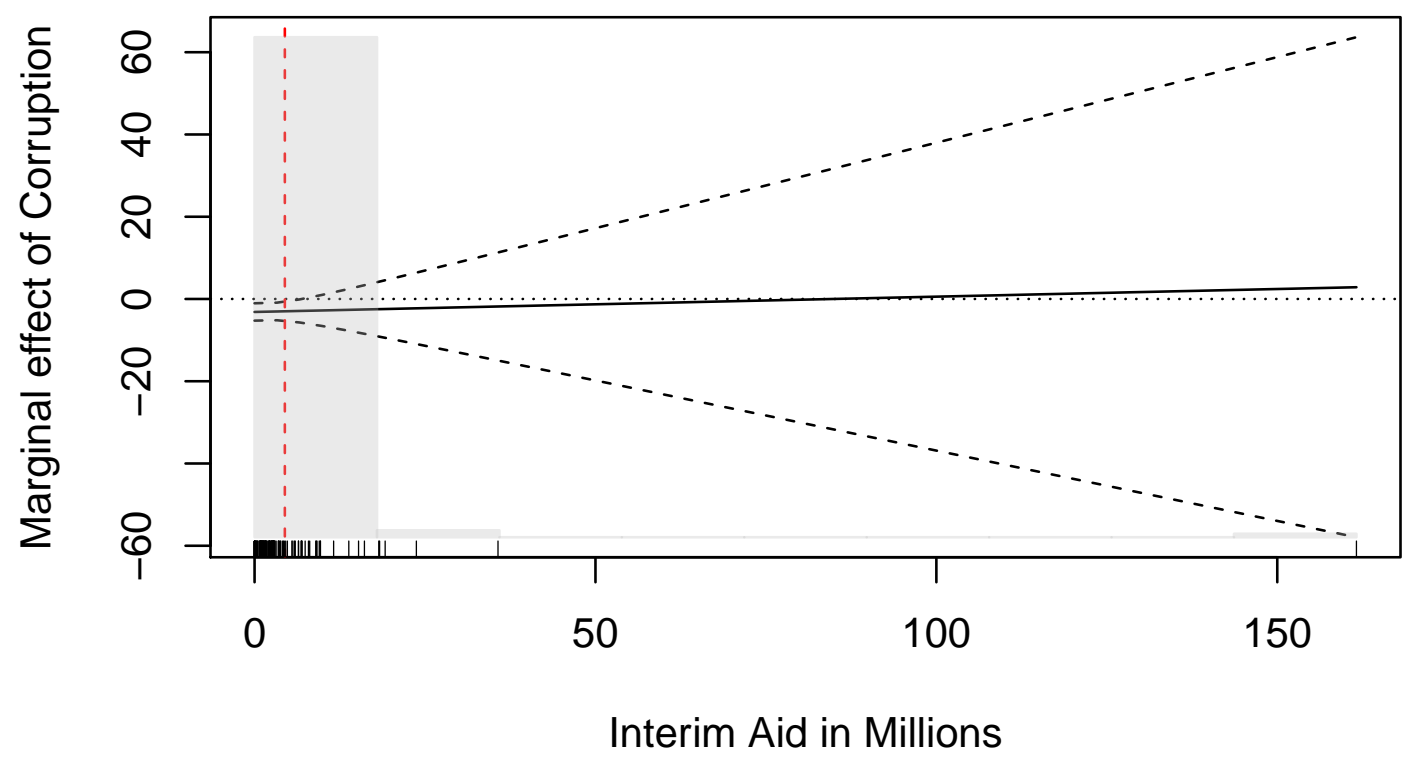

Interim aid has no effect on duration . It is only statistically significant 1 in 4 regressions, and when it is statistically significant, it is negative. This result is surprising since shortening the interim duration is the sole purpose of interim aid provision. However, interim aid is significant if it is squared (again, negative), which implies that more interim aid can cause longer duration. Institutional variables of corruption and low rule of law increase interim

\footnotetext{
${ }^{7}$ For more information, see Understanding Interaction Models: Improving Empirical Analyses by Brambor, Clark, and Golder. 2006. Political Analysis 14, 63-82.
} 
Figure 2.4: Marginal Effects of Interim Aid per capita on Interim Duration on different levels of Corruption

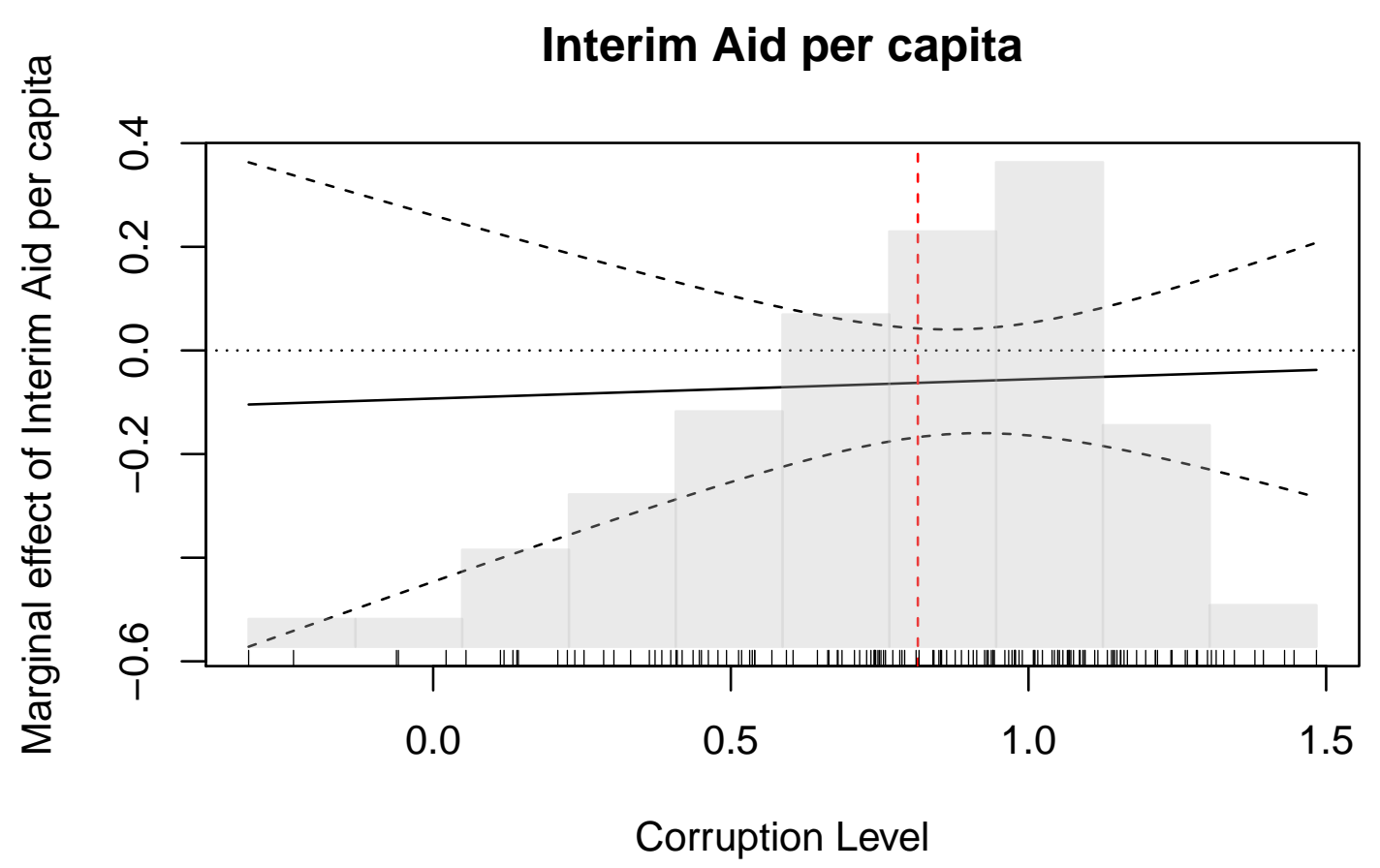

duration. This is not surprising because lower institutional quality can lead to inefficient use of time, capital, interim aid which lengthens interim duration.

The interaction between HIPC aid and corruption yields a statistically insignificant negative coefficient. Figure 2.5 illustrates the survival functions of two group of countries, one with higher interim aid and higher corruption vs. one with low interim aid and lower corruption. The location of the curves suggest that countries with relatively higher aid and corruption survive longer. This indicates that countries with lower corruption finish more quickly. However, since the interaction term is not statistically significant, I do not find any evidence in favor of moral hazard.

As a further robustness check, I also regress the interaction between Interim Aid squared and Corruption (low rule of law) and received the same result of statistically insignificant coefficients. The effect of aid is not as strong as corruption or the rule of law. Countries with 
Figure 2.5: Kaplan-Meier Survival Function, Interaction Term of Aid and Corruption

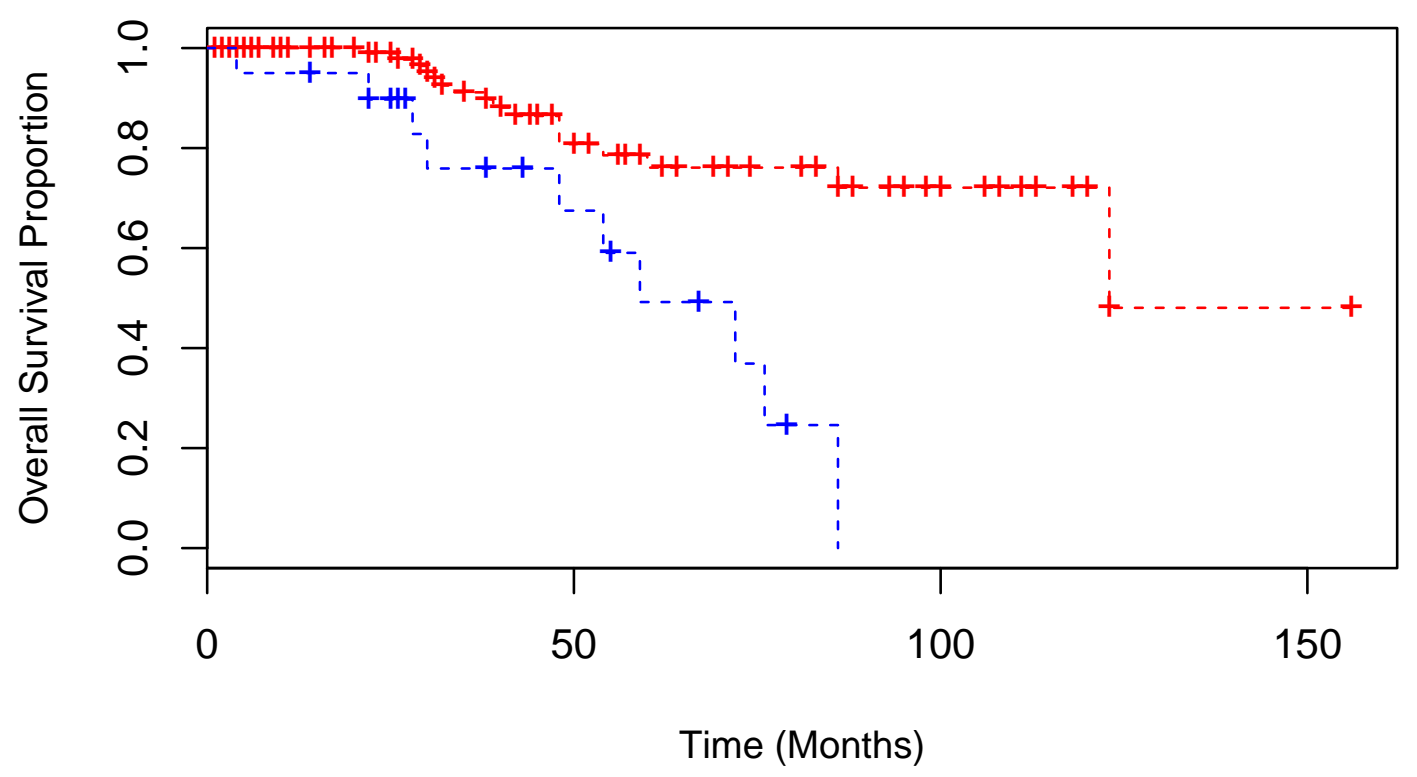

lower rule of law or higher corruption level stay in the interim period longer. However, since both results (aid $\mathrm{x}$ institution and aid squared $\mathrm{x}$ institution) are statistically insignificant, they suggest that there is not moral hazard.

Macroeconomic status variables yield mixed results. Initial GDP level does not have an effect on duration. High inflation, higher real GDP per capita growth, and higher combined polity score are statistically insignificant. And surprisingly, having conflict (war) in a country does not affect its ability to reach the completion point. Countries with higher debt service to GNI have longer interim period, while countries receiving more official development aid finish earlier.

Countries that joined the HIPC program under the original framework also reach the completion point faster. They have more time to implement their PRSP strategies. However, one unexpected result is the negative coefficient from Openness to Trade. Countries with higher exports perform worse in term of reaching the completion point. Geography 
does not have a consistent effect on interim duration. Absolute latitude is not statistically significant and the African country indicator variable only has an effect sporadically.

The results show that interim aid does not affect interim duration even though it is provided to help shorten the interim duration. And, countries with better (poorer) control of corruption stay shorter (longer) in the interim period. Interaction terms between interim debt relief and institutional quality are not statistically significant; therefore, I do not find evidence of moral hazard.

\subsection{Conclusion}

This paper has three main objectives: (1) finding cross-country characteristics that determine HIPC interim duration, (2) connecting the institutional quality of each country with the ability to exit the HIPC program, and (3) investigating if there exists any moral hazard in the HIPC initiative debt relief process. After testing each objective and receiving consistent result using two different policy variables, I have the following findings: (1) Characteristics that lead to longer interim period are higher corruption, lower rule of law, higher debt service to GNI ratio, being more open to trade, and being in the African continent. (2) The ability for each country to exit the decision point is tied to institutional quality. Both policy variables (corruption and low rule of law) resulted in negative coefficients; thus longer interim period. (3) I do not find evidence of moral hazard due to the fact that the interaction term (between aid and institutional quality) is statistically insignificant.

This study presents an analysis into the issue of the effectiveness of the HIPC aid and the incentives for moral hazard in the HIPC debt relief literature. The modest contribution that this paper makes is the revelation that the interim aid provided by the IMF and the World Bank does not accomplish the goal of shorter interim period. Since high corruption and a low rule of law are associated with longer interim period, I recommend that the IMF and the World Bank pay more attention to institutional quality of the recipient countries. 
Table 2.1: Variable Description and Sources

\begin{tabular}{ll}
\hline Variable & Description \\
\hline $\begin{array}{l}\text { Dependent Variable } \\
\text { Time in months }\end{array}$ & $\begin{array}{l}\text { Running total number of months coun- } \\
\text { try i has been in the Decision Point of } \\
\text { the HIPC Program. }\end{array}$
\end{tabular}

Main Variables of Interest

HIPC Interim Aid

Corruption

HIPCaid x Corruption

Low ROL

HIPCaid $\mathrm{x}$ Low ROL

Macroeconomic Status Variables In original HIPC framework

initial GDP per capita

In conflict

inflation

Debt Service to GNI

Net ODA in billions

openness

GDP per capita growth

Revised Polity

\section{Geography Variables} Africa
Yearly HIPC interim aid in billions.

Control of corruption estimate measures the perceptions of corruption in the country (using public power for private gain) $\mathrm{x}-1$

interaction variable: HIPC Interim Aid $\mathrm{x}$ Corruption

Rule of law estimate measures the confidence that citizens have in and abide by the rules of society (how much is property rights protected?) $\mathrm{x}-1$

interaction variable: HIPC Interim Aid $x$ ROL

Dummy variable: 1 if the country started in the original HIPC framework Real GDP per capita of country i during the first year it enters the Decision Point.

value of 1 if country is in a conflict, 0 otherwise

Inflation rate (growth rate of GDP implicit deflator).

Total debt service as a percentage of GNI. Debt repayments and interests.

Net official development aid, in billions

higher openness to trade. Exports plus imports, divided by real GDP per capita, in constant price.

Per Capita GDP growth

Revised Combined Polity Score

value 1 if country is located in the African continent, 0 otherwise
Source

World Bank document: Heavily Indebted Poor Countries (HIPC) Initiative and Multilateral Debt Relief Initiative (MDRI) - Status of Implementation and Proposals for the Future of the HIPC Initiative. November 8, 2011.

Calculated by the author from data obtained in the World Bank and International Monetary Fund yearly reports

World Bank: The Worldwide Governance Indicators. Kauffman et al (2009)

calculated by the author

World Bank: The Worldwide Governance Indicators. Kauffman et al (2009)

calculated by the author

World Bank documents

\section{UCDP/PRIO Conflict Database}

World Bank: The Worldwide Governance Indicators. Kauffman et al (2009)

World Bank: The Worldwide Governance Indicators. Kauffman et al (2009) World Bank: The Worldwide Governance Indicators. Kauffman et al (2009)

Heston, Summers, Aten (2012)

World Bank: The Worldwide Governance Indicators. Kauffman et al (2009) Polity IV Project Data Set. (Marshall \& Jaggers 2011)

author made by looking at the world map 
Table 2.2: HIPC Decision and Completion Point Dates

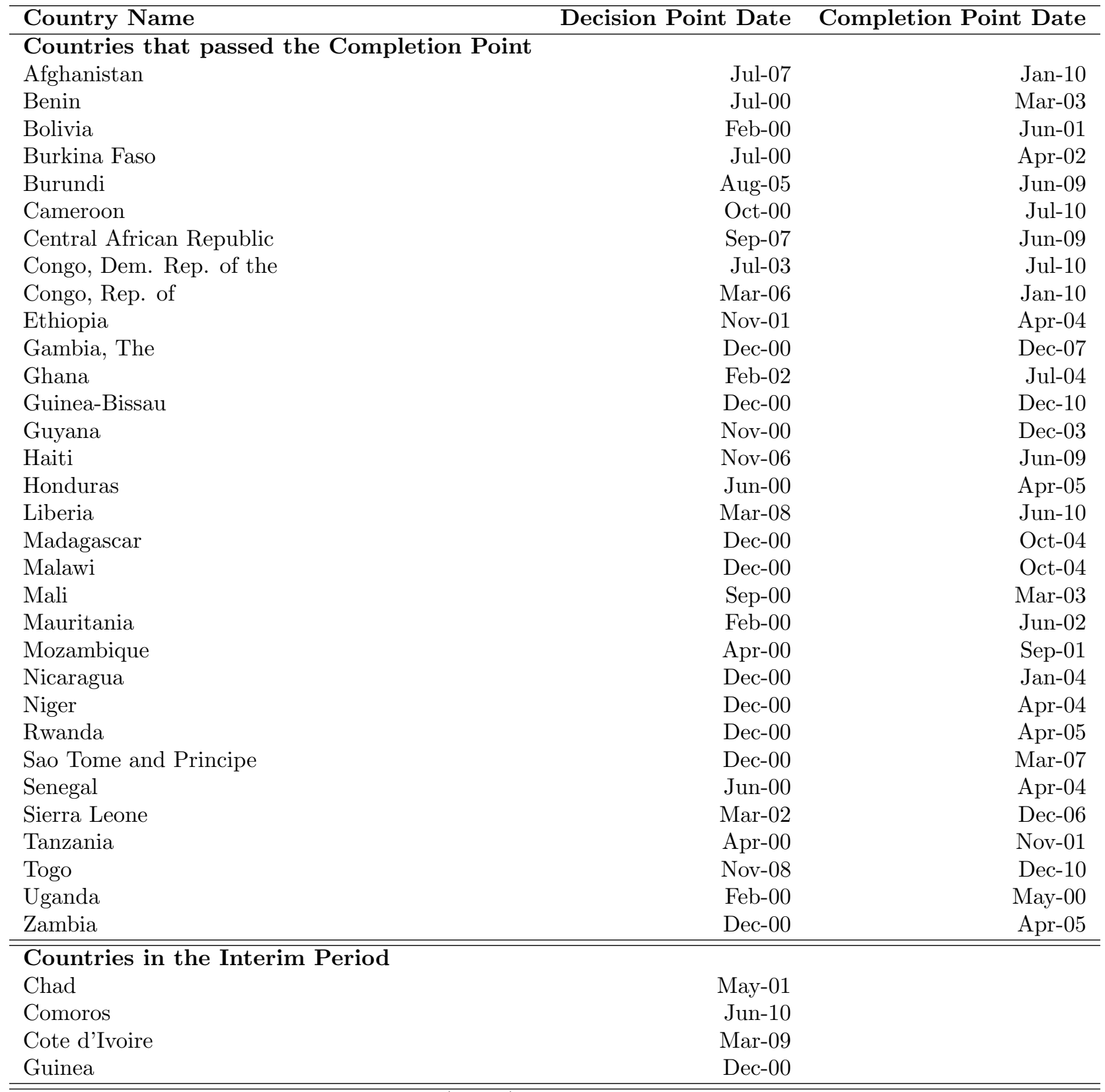

Source: Heavily Indebted Poor Countries (HIPC) Initiative and Multilateral Debt Relief Initiative (MDRI) - Status of Implementation and Proposals for the Future of the HIPC Initiative. November 8, 2011. 
Table 2.3: Countries in the Data Set

\begin{tabular}{|c|c|c|}
\hline Country Name & Total Relief (millions) & Included \\
\hline Afghanistan & $\$ 1,319$ & No \\
\hline Benin & $\$ 1,604$ & No \\
\hline Bolivia & $\$ 4,889$ & Yes \\
\hline Burkina Faso & $\$ 2,160$ & Yes \\
\hline Burundi & $\$ 1,474$ & Yes \\
\hline Cameroon & $\$ 6,209$ & Yes \\
\hline Central African Republic & $\$ 1,110$ & Yes \\
\hline Congo, Democratic Republic of & $\$ 16,273$ & Yes \\
\hline Congo, Republic of & $\$ 1,934$ & Yes \\
\hline Ethiopia & $\$ 6,584$ & Yes \\
\hline Gambia, The & $\$ 498$ & Yes \\
\hline Ghana & $\$ 7,405$ & Yes \\
\hline Guinea Bissau & $\$ 790$ & Yes \\
\hline Guyana & $\$ 2,063$ & Yes \\
\hline Haiti & $\$ 1,175$ & Yes \\
\hline Honduras & $\$ 3,723$ & Yes \\
\hline Liberia & $\$ 4,861$ & Yes \\
\hline Madagascar & $\$ 4,315$ & Yes \\
\hline Malawi & $\$ 3,224$ & Yes \\
\hline Mali & $\$ 2,904$ & Yes \\
\hline Mauritania & $\$ 1,990$ & Yes \\
\hline Mozambique & $\$ 6,347$ & Yes \\
\hline Nicaragua & $\$ 6,413$ & Yes \\
\hline Niger & $\$ 2,264$ & Yes \\
\hline Rwanda & $\$ 1,835$ & Yes \\
\hline Sao Tome Principe & $\$ 334$ & No \\
\hline Senegal & $\$ 3,339$ & Yes \\
\hline Sierra Leone & $\$ 1,664$ & Yes \\
\hline Tanzania & $\$ 6,842$ & Yes \\
\hline Togo & $\$ 360$ & Yes \\
\hline Uganda & $\$ 5,474$ & Yes \\
\hline Zambia & $\$ 6,670$ & Yes \\
\hline Chad & & Yes \\
\hline Comoros & & Yes \\
\hline Cote d'Ivoire & & Yes \\
\hline Guinea & & Yes \\
\hline
\end{tabular}


Table 2.4: Descriptive Statistics

\begin{tabular}{lcccccc}
\hline \hline Statistic & $\mathrm{N}$ & Mean & St. Dev. & Min & Median & Max \\
\hline InterimAid & 147 & 4.437 & 13.967 & 0.000 & 1.801 & 161.612 \\
corrupt & 147 & 0.814 & 0.374 & -0.310 & 0.887 & 1.484 \\
lowrol & 147 & 0.923 & 0.469 & -0.163 & 1.038 & 1.629 \\
original & 147 & 0.224 & 0.419 & 0 & 0 & 1 \\
inflation & 147 & 9.722 & 12.416 & -20.627 & 6.208 & 95.853 \\
netoda & 147 & 74.137 & 56.777 & 5.899 & 58.955 & 355.337 \\
polity & 147 & 2.027 & 4.578 & -6 & 5 & 9 \\
openness & 147 & 66.431 & 29.058 & 26.335 & 61.293 & 182.129 \\
AbsLat & 147 & 0.503 & 0.502 & 0 & 1 & 1 \\
debtsvc & 147 & 4.161 & 11.161 & 0.552 & 2.356 & 135.247 \\
conflict & 147 & 0.088 & 0.285 & 0 & 0 & 1 \\
africa & 147 & 0.884 & 0.321 & 0 & 1 & 1 \\
initGDPpc & 147 & $1,270.801$ & 798.763 & 255.748 & $1,028.174$ & $3,566.994$ \\
rGDPpcg & 147 & 1.515 & 4.521 & -15.306 & 1.169 & 29.104 \\
\hline
\end{tabular}




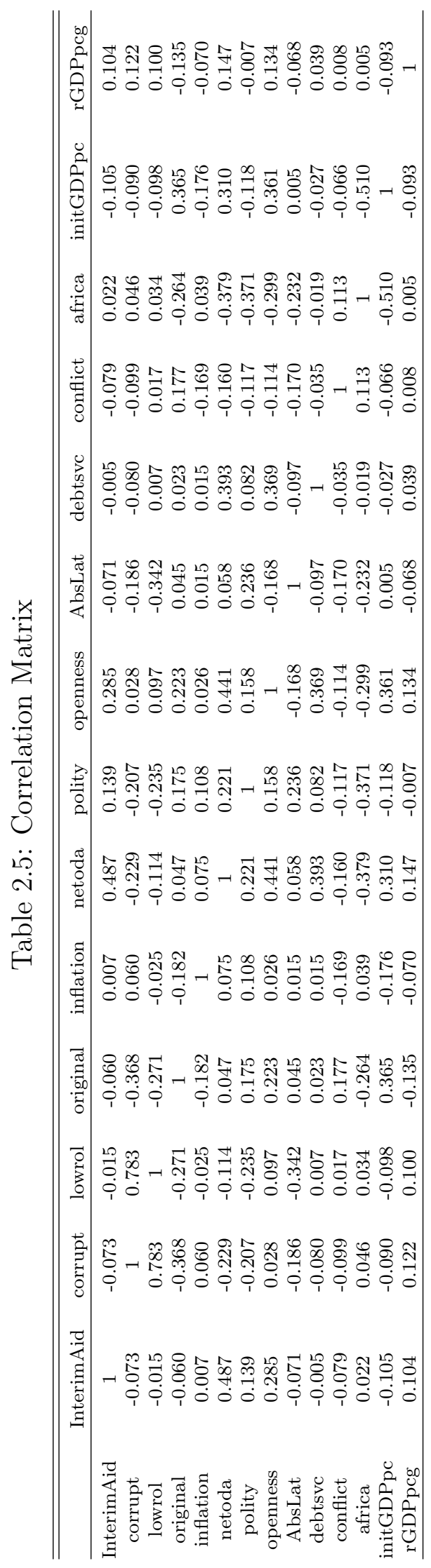


Table 2.6: Cox Proportional Hazard: Corruption

\begin{tabular}{|c|c|c|c|c|}
\hline & \multicolumn{4}{|c|}{ Months in the Interim Period } \\
\hline & \multicolumn{4}{|c|}{ time } \\
\hline & $(1)$ & $(2)$ & (3) & $(4)$ \\
\hline InterimAid & $\begin{array}{l}-0.018 \\
(0.020)\end{array}$ & $\begin{array}{l}-0.093 \\
(0.180)\end{array}$ & & \\
\hline aidsq & & & $\begin{array}{c}0.00000 \\
(0.00000)\end{array}$ & $\begin{array}{r}-0.00002^{*} \\
(0.00001)\end{array}$ \\
\hline corrupt & $\begin{array}{c}-2.406^{* * *} \\
(0.860)\end{array}$ & $\begin{array}{c}-3.155^{* * *} \\
(1.076)\end{array}$ & $\begin{array}{c}-2.602^{* * *} \\
(0.861)\end{array}$ & $\begin{array}{c}-5.427^{* * *} \\
(1.330)\end{array}$ \\
\hline initGDPpc & $\begin{array}{c}-0.003^{* * *} \\
(0.001)\end{array}$ & $\begin{array}{c}-0.002^{* * *} \\
(0.001)\end{array}$ & $\begin{array}{c}-0.002^{* * *} \\
(0.001)\end{array}$ & $\begin{array}{c}-0.003^{* * *} \\
(0.001)\end{array}$ \\
\hline rGDPpcg & $\begin{array}{c}-0.008 \\
(0.079)\end{array}$ & $\begin{array}{c}0.003 \\
(0.064)\end{array}$ & $\begin{array}{l}-0.014 \\
(0.084)\end{array}$ & $\begin{array}{l}-0.078 \\
(0.092)\end{array}$ \\
\hline inflation & $\begin{array}{l}-0.001 \\
(0.027)\end{array}$ & $\begin{array}{l}-0.006 \\
(0.023)\end{array}$ & $\begin{array}{c}0.006 \\
(0.023)\end{array}$ & $\begin{array}{l}-0.018 \\
(0.030)\end{array}$ \\
\hline debtsvc & $\begin{array}{c}-0.316^{*} \\
(0.185)\end{array}$ & $\begin{array}{l}-0.121 \\
(0.141)\end{array}$ & $\begin{array}{l}-0.273 \\
(0.179)\end{array}$ & $\begin{array}{c}-0.363^{*} \\
(0.214)\end{array}$ \\
\hline netoda & $\begin{array}{c}0.026^{* * *} \\
(0.008)\end{array}$ & $\begin{array}{c}0.010 \\
(0.009)\end{array}$ & $\begin{array}{c}0.019^{* * *} \\
(0.006)\end{array}$ & $\begin{array}{l}0.016^{* *} \\
(0.008)\end{array}$ \\
\hline polity & $\begin{array}{l}-0.016 \\
(0.057)\end{array}$ & $\begin{array}{l}-0.110 \\
(0.072)\end{array}$ & $\begin{array}{l}-0.026 \\
(0.057)\end{array}$ & $\begin{array}{l}-0.068 \\
(0.064)\end{array}$ \\
\hline openness & $\begin{array}{l}-0.016 \\
(0.013)\end{array}$ & $\begin{array}{l}-0.001 \\
(0.012)\end{array}$ & $\begin{array}{c}-0.028^{* *} \\
(0.013)\end{array}$ & $\begin{array}{l}-0.010 \\
(0.015)\end{array}$ \\
\hline original & $\begin{array}{c}2.657^{* * *} \\
(0.823)\end{array}$ & $\begin{array}{c}1.974^{* * *} \\
(0.719)\end{array}$ & $\begin{array}{c}2.635^{* * *} \\
(0.818)\end{array}$ & $\begin{array}{c}2.926^{* * *} \\
(0.866)\end{array}$ \\
\hline conflict & $\begin{array}{l}1.246 \\
(0.861)\end{array}$ & $\begin{array}{c}0.486 \\
(0.832)\end{array}$ & $\begin{array}{c}1.200 \\
(0.857)\end{array}$ & $\begin{array}{c}1.286 \\
(0.889)\end{array}$ \\
\hline africa & $\begin{array}{c}-3.443^{* * *} \\
(1.191)\end{array}$ & $\begin{array}{c}-2.695^{* * *} \\
(0.880)\end{array}$ & $\begin{array}{c}-3.967^{* * *} \\
(1.121)\end{array}$ & $\begin{array}{c}-3.903^{* * *} \\
(0.923)\end{array}$ \\
\hline AbsLat & $\begin{array}{l}-0.892 \\
(0.582)\end{array}$ & $\begin{array}{l}-0.314 \\
(0.495)\end{array}$ & $\begin{array}{l}-0.628 \\
(0.553)\end{array}$ & $\begin{array}{l}-0.961 \\
(0.669)\end{array}$ \\
\hline InterimAid:corrupt & & $\begin{array}{c}0.037 \\
(0.194)\end{array}$ & & \\
\hline aidsq:corrupt & & & & $\begin{array}{c}0.00002^{* *} \\
(0.00001)\end{array}$ \\
\hline corrupt:netoda & & $\begin{array}{c}0.014 \\
(0.009)\end{array}$ & & $\begin{array}{c}0.026^{* * *} \\
(0.009)\end{array}$ \\
\hline PHazard global test & $\mathrm{p} i 0.10$ & $\mathrm{p} i 0.10$ & $\mathrm{p} i 0.10$ & $\mathrm{p} i \mathrm{i} 0.10$ \\
\hline Observations & 147 & 147 & 147 & 147 \\
\hline $\mathrm{R}^{2}$ & 0.368 & 0.243 & 0.366 & 0.412 \\
\hline Max. Possible $\mathrm{R}^{2}$ & 0.766 & 0.766 & 0.766 & 0.766 \\
\hline Log Likelihood & -73.134 & -86.424 & -73.391 & -67.818 \\
\hline Wald Test & $46.350^{* * *}$ & $33.770^{* * *}$ & $46.120^{* * *}$ & $41.900^{* * *}$ \\
\hline LR Test & $67.549^{* * *}$ & $40.969^{* * *}$ & $67.035^{* * *}$ & $78.181^{* * *}$ \\
\hline Score (Logrank) Test & $94.153^{* * *}$ & $94.575^{* * *}$ & $90.724^{* * *}$ & $93.791^{* * *}$ \\
\hline
\end{tabular}

Note: $\quad{ }^{*} \mathrm{p}<0.1 ;{ }^{* *} \mathrm{p}<0.05 ;{ }^{* * *} \mathrm{p}<0.01$

Standard errors are in parenthesis

Negative coefficients mean lower hazard.

Lower hazard implies a longer duration. 
Table 2.7: Cox Proportional Hazard: Rule of Law

\begin{tabular}{|c|c|c|c|c|}
\hline & \multicolumn{4}{|c|}{ Months in the Interim Period } \\
\hline & \multicolumn{4}{|c|}{ time } \\
\hline & $(1)$ & $(2)$ & $(3)$ & $(4)$ \\
\hline InterimAid & $\begin{array}{c}-0.033^{*} \\
(0.020)\end{array}$ & $\begin{array}{c}0.012 \\
(0.146)\end{array}$ & & \\
\hline aidsq & & & $\begin{array}{c}0.00000 \\
(0.00001)\end{array}$ & $\begin{array}{c}-0.00003^{*} \\
(0.00002)\end{array}$ \\
\hline lowrol & $\begin{array}{c}-2.942^{* * *} \\
(0.746)\end{array}$ & $\begin{array}{c}-3.422^{* * *} \\
(1.198)\end{array}$ & $\begin{array}{c}-2.831^{* * *} \\
(0.731)\end{array}$ & $\begin{array}{c}-3.839^{* * *} \\
(1.193)\end{array}$ \\
\hline initGDPpc & $\begin{array}{c}-0.003^{* * *} \\
(0.001)\end{array}$ & $\begin{array}{c}-0.003^{* * *} \\
(0.001)\end{array}$ & $\begin{array}{c}-0.002^{* * *} \\
(0.001)\end{array}$ & $\begin{array}{c}-0.003^{* * *} \\
(0.001)\end{array}$ \\
\hline rGDPpcg & $\begin{array}{l}-0.055 \\
(0.088)\end{array}$ & $\begin{array}{l}-0.047 \\
(0.091)\end{array}$ & $\begin{array}{l}-0.050 \\
(0.092)\end{array}$ & $\begin{array}{l}-0.077 \\
(0.096)\end{array}$ \\
\hline inflation & $\begin{array}{l}-0.010 \\
(0.030)\end{array}$ & $\begin{array}{l}-0.014 \\
(0.031)\end{array}$ & $\begin{array}{l}0.007 \\
(0.021)\end{array}$ & $\begin{array}{l}-0.011 \\
(0.029)\end{array}$ \\
\hline debtsvc & $\begin{array}{c}-0.386^{* *} \\
(0.195)\end{array}$ & $\begin{array}{c}-0.346^{*} \\
(0.202)\end{array}$ & $\begin{array}{c}-0.370^{*} \\
(0.198)\end{array}$ & $\begin{array}{c}-0.408^{*} \\
(0.214)\end{array}$ \\
\hline netoda & $\begin{array}{c}0.036^{* * *} \\
(0.008)\end{array}$ & $\begin{array}{l}0.029^{* *} \\
(0.012)\end{array}$ & $\begin{array}{c}0.026^{* * *} \\
(0.006)\end{array}$ & $\begin{array}{l}0.026^{* *} \\
(0.012)\end{array}$ \\
\hline polity & $\begin{array}{l}-0.077 \\
(0.060)\end{array}$ & $\begin{array}{l}-0.069 \\
(0.068)\end{array}$ & $\begin{array}{l}-0.076 \\
(0.060)\end{array}$ & $\begin{array}{l}-0.091 \\
(0.060)\end{array}$ \\
\hline openness & $\begin{array}{l}-0.013 \\
(0.013)\end{array}$ & $\begin{array}{l}-0.013 \\
(0.013)\end{array}$ & $\begin{array}{c}-0.031^{* *} \\
(0.014)\end{array}$ & $\begin{array}{l}-0.018 \\
(0.016)\end{array}$ \\
\hline original & $\begin{array}{c}2.636^{* * *} \\
(0.768)\end{array}$ & $\begin{array}{c}2.823^{* * *} \\
(0.821)\end{array}$ & $\begin{array}{c}2.854^{* * *} \\
(0.784)\end{array}$ & $\begin{array}{c}2.811^{* * *} \\
(0.827)\end{array}$ \\
\hline conflict & $\begin{array}{l}1.854^{* *} \\
(0.898)\end{array}$ & $\begin{array}{l}1.731^{*} \\
(0.916)\end{array}$ & $\begin{array}{l}1.721^{*} \\
(0.894)\end{array}$ & $\begin{array}{l}1.814^{*} \\
(0.926)\end{array}$ \\
\hline africa & $\begin{array}{c}-3.948^{* * *} \\
(1.117)\end{array}$ & $\begin{array}{c}-3.888^{* * *} \\
(1.078)\end{array}$ & $\begin{array}{c}-4.574^{* * *} \\
(1.176)\end{array}$ & $\begin{array}{c}-4.127^{* * *} \\
(1.071)\end{array}$ \\
\hline AbsLat & $\begin{array}{c}-1.543^{* *} \\
(0.656)\end{array}$ & $\begin{array}{c}-1.528^{* *} \\
(0.652)\end{array}$ & $\begin{array}{c}-1.060^{*} \\
(0.583)\end{array}$ & $\begin{array}{c}-1.387^{* *} \\
(0.646)\end{array}$ \\
\hline InterimAid:lowrol & & $\begin{array}{l}-0.051 \\
(0.148)\end{array}$ & & \\
\hline aidsq:lowrol & & & & $\begin{array}{l}0.00002^{*} \\
(0.00001)\end{array}$ \\
\hline lowrol:netoda & & $\begin{array}{c}0.011 \\
(0.013)\end{array}$ & & $\begin{array}{c}0.010 \\
(0.013) \\
\end{array}$ \\
\hline PHazard global test & $\mathrm{p} i 0.10$ & $\mathrm{p} i 0.10$ & $\mathrm{p} i 0.10$ & $\mathrm{p} i 0.10$ \\
\hline Observations & 147 & 147 & 147 & 147 \\
\hline $\mathrm{R}^{2}$ & 0.411 & 0.414 & 0.400 & 0.415 \\
\hline Max. Possible $\mathrm{R}^{2}$ & 0.766 & 0.766 & 0.766 & 0.766 \\
\hline Log Likelihood & -67.985 & -67.607 & -69.322 & -67.564 \\
\hline Wald Test & $48.190^{* * *}$ & $47.300^{* * *}$ & $47.400^{* * *}$ & $44.110^{* * *}$ \\
\hline LR Test & $77.846^{* * *}$ & $78.603^{* * *}$ & $75.174^{* * *}$ & $78.689^{* * *}$ \\
\hline Score (Logrank) Test & $92.808^{* * *}$ & $94.335^{* * *}$ & $89.759^{* * *}$ & $93.186^{* * *}$ \\
\hline
\end{tabular}

Note: $\quad{ }^{*} \mathrm{p}<0.1 ;{ }^{* *} \mathrm{p}<0.05 ;{ }^{* * *} \mathrm{p}<0.01$

Standard errors are in parenthesis.

Negative coefficients mean lower hazard.

Lower hazard implies a longer duration. 


\section{Chapter 3}

\section{Spatial Spillover Effects of Debt Relief from the Heavily Indebted Poor Countries (HIPC) Initiative}

\subsection{Introduction}

Every year billions of dollars of aid is provided to nations in need to help them increase their standard of living. According to the Development Assistance Committee (DAC), \$127.3 billion of net official development aid (ODA) was disbursed in 2010. Foreign aid can be given as loans, grants, and debt relief. Unfortunately, many countries obtain such a large amount of loans that they are unable to repay them back without borrowing more. Eventually, their outstanding balance becomes a shadow that haunts them. Krugman (1988) describes this condition as a debt overhang problem. Debt overhang is an important issue because debt-ridden countries will have trouble attracting new investments, and they have to direct resources to repay their oversized debt. Reinhart, Reinhart, and Rogoff (2012) identify two channels through which public debt overhang leads to lower growth; they are private investments and risk premium on the interest rates government debt.

This situation is similar to a corporation taking on so much debt that it becomes impossible to service the debt payments and hence, it files for bankruptcy. When a country 
is in this situation, the HIPC Initiative is there to provide assistance to them. The Heavily Indebted Poor Countries (HIPC) Initiative's goal is to alleviate the debt burden of these countries so that they can accomplish the Millennium Development Goals (MDGs). These goals cover a wide array of well-being measures, such as the eradication of extreme poverty and hunger, and combat against HIV/AIDS and malaria.

Past research has indicated that spatial correlation should be considered when analyzing the impacts of public policy (Lacombe, 2004). When the correlation parameters are not zero, then the least-squares method yields biased and inconsistent estimates. I test my data set and find spatial correlations; hence, I use a spatial econometric methods to investigate the impact of the HIPC debt relief efforts. In particular, my paper looks at the amount of debt relief that each country receives from HIPC Initiative and investigates whether it positively, or negatively, affects the recipient nation's GDP per capita, and whether its effect carries over to its surrounding neighbors. I employ the Spatial Durbin Model (SDM) to find the answer. The SDM regression results reveal a correlation between GDP per capita of neighboring countries. Furthermore, there are spillover effects of the HIPC membership into nearby countries. When country $i$ is part of the HIPC Initiative, neighboring country $j$ 's GDP per capita suffers.

Using spatial analysis to investigate international spillover effects is a relatively new contribution. Murdoch and Sandler (2001) find long-run and short-run effects of civil wars on income per-capita growth in the host country and its neighbors. They find that there are spillover effects to the neighboring countries. The effects are stronger in the short-run compared to the long-run. Their policy implication is that countries neighboring civil war stricken countries also need foreign assistance. Therefore, a conflict (war) is a channel through which one country's situation can affect the neighbor's GDP.

Another channel that affects income level is institutional quality (North (1990), Gwartney et al. (1999), Rodrik et al. (2004), Acemoglu and Johnson (2005), Young and Sheehan (2014)). Kelejian, Murrell, and Shepotylo (2008) use the Spatial Autocorrelation (SAC) 
model to examine spatial spillovers between countries in the development of institutions. They employ a counter-factual way of looking at the direct and indirect effects of spatial spillovers. Their conclusion is that, in the long run, governance quality spills outside of the country's borders. A possible policy implication of their paper is to encourage and incentivize institutional development in both recipient and neighboring countries. Hosseini and Kaneko (2012) find spatial spillovers of good governance, government effectiveness, and rule of law.

Another spillover channel is foreign investments. Shepotylo (2010) provides evidence that there are spatial links in foreign direct investment (FDI) between a recipient country and its neighbors. They argue that FDI models are misspecified if they omit spatial effects of FDI flows. He uses a Spatial AutoRegressive (SAR) model and finds spatial spillovers more in disaggregate data. With 1993-2007 data, he runs the SAR and the Spatial Error Model (SEM) using the Maximum Likelihood method. His paper estimates the degree of spatial spillovers of FDI and influence of foreign market potential on FDI in transition countries.

This paper expands the field of international development by using a spatial econometrics model to shed light on the issue of whether HIPC debt relief brings benefit or harm to recipient countries and their neighbors. I use a spatial weight matrix that account for neighbors, in term of geographical location. Proximity to a country receiving a large debt relief package can affect the surrounding countries. I provide the correct direct and indirect effects estimates according to LeSage and Pace (2009). After the effects are estimated, the results seem to suggest that HIPC membership has negative effects on its recipient country and surrounding neighbors.

This paper proceeds as follows. Section 3.2 introduces the HIPC and MDRI debt relief initiatives. Section 3.3 describes the data used. Section 3.4 outlines the model selection procedures. Section 3.5 summarizes the regression results, and Section 3.6 concludes the paper. 


\subsection{Background on the HIPC Initiative and the MDRI}

The Heavily Indebted Poor Countries (HIPC) Initiative is a joint effort program created by the World Bank and the International Monetary Fund (IMF) to help poor nations accomplish the Millennium Development Goals (MDGs). The HIPC Initiative was launched in 1996 and was later enhanced in 1999. The Multilateral Debt Relief Initiative (MDRI) was created in 2006 to supplement HIPC countries with more financial support.

HIPC Initiative calls for the voluntary debt relief by creditors. It could serve in a creditor's interest to forgive some debt to get these HIPC countries to a more sustainable debt level so that the debtors will increase the chance of repayment on their loans. Creditors can be commercial, bilateral, such as the Paris club, and multilateral creditors, such as the World Bank.

The HIPC Initiative process mainly involves two stages: the Decision Point and the Completion Point. The HIPC Initiative and MDRI provide aid and debt relief to countries that are struggling to service their debt. However, to qualify for HIPC and MDRI (from here on, HIPC will mean both HIPC and MDRI) Initiatives' aid, countries must satisfy certain criteria. Once they meet these conditions, then they receive irrevocable aid that arrives in a lump sum payment. The large package of debt relief that ranges from hundreds of millions to several billions of dollars. As of December 2011, the list of countries that have qualified or potentially eligible for HIPC aid is listed in Table 3.1 and 3.2 .

\subsection{Data}

This paper uses two datasets. The first data set has 63 countries (set A), 36 of which are HIPCs, and 27 of which are the neighbors of HIPCs. The second dataset includes 56 countries (set B), which contains all countries in the 63-countries except for the seven island countries. Island countries do not have contiguous neighbors. However, a rational for including the seven island countries is technology. Since island countries have bridges, ferries, cargo ships, 
and planes that enable them to perform business transactions with foreign countries, they may have spatial relationships with other countries. The regressions performed on set A should be viewed as a robustness check. The estimates of spatial parameters are statistically significant in all models, which helps confirm the robustness of the results.

\subsubsection{Dependent Variable}

Both data set, A and B, cover the 1999-2010 time frame. The year 1999 is when the HIPC Initiative was enhanced and when countries started their reform to enter the decision point. The dependent variable is the change in $\log$ of the real GDP per capita [ $\log$ (end real GDP per capita) - $\log$ (initial real GDP per capita]. The real values use the base year of 2005. The average initial real GDP per capita is $\$ 2812.42$ while the average ending real GDP per capita is $\$ 4211.71$. The source of this variable is the World Bank's World Development Indicator data base.

\subsubsection{Explanatory Variables}

Explanatory variables are the amount of total (cumulative sum) HIPC debt relief per capita, (HIPCrelief), the dummy variable to indicate whether a country belongs to the HIPC Initiative, (member), and the duration that a HIPC Initiative member has stayed in the interim period so far, (months). Total HIPC debt relief per capita, (HIPCrelief), amounts are in millions of US dollars divided by the population in millions. Since 27 countries in the data set do not receive HIPC debt relief, HIPCrelief equals a zero for these countries; hence, I cannot use the log of the variable. My anticipation is that this amount of debt relief will not only impact the recipient country's real GDP per capita but it will also impact the surrounding neighbors'. Therefore, I include these 27 neighboring countries in my analysis.

I also use the member variable to measure the impact of being a member of the HIPC Initiative. This variable takes a ' 1 ' if a country is a HIPC member, and a ' 0 ' otherwise. I aim to find the impact of being a HIPC member, regardless of the debt relief amount. The 
months variable also allows me to measure the effect of being a HIPC member, regardless of the debt relief amount. This variable measures the time, in months, that country $i$ spends in the interim period. These two explanatory variables give us the non-monetary component of the HIPC Initiative membership.

\subsubsection{Control Variables}

The additional control variables are the rule of law index, the polity score, the conflict indicator, the inflation rate, the net official development aid (ODA) per capita amount, net inflows of foreign direct investment, the public health expenditure ratio, the absolute latitude, and the dummy variable indicating whether a country is landlocked. All of these data are from the World Bank's World Development Indicator database. These variables are averages from the year 1999 to year 2010. The starting year is 1999 because even though HIPC Initiative was formed in 1996, but its first debt relief package was released in 1999.

The rule of law index ranges from -2.5 to 2.5 , with 2.5 being the relatively better rule. This variable serves as a control for government quality. As mentioned in Burnside and Dollar (2000), aid can be ineffective unless the recipient country has well established institutions. I also use the combined polity score from the Polity IV project that grades political regimes. ${ }^{1}$ The combine polity score ranges from -10 to +10 , strongly autocratic to strongly democratic, respectively.

The conflict dummy variable serves as a proxy for a war ridden country. If country $i$ has battle related deaths in a year, the dummy variable takes ' 1 ', and ' 0 ' otherwise. Numerous African nations face dictator regimes or genocide or civil war that stripped them the ability to progress. Therefore, the battle death counts for conflict effects.

The inflation rate is the average of the country's annual inflation rate over the 1999-2010 period. The HIPC Initiative requires that recipient countries improve their macroeconomic

\footnotetext{
${ }^{1}$ The Polity IV Project: Political Regime Characteristics and Transitions, 1800-2011 by Marshall and Jaggers: http://www.systemicpeace.org/polity/polity4.htm
} 
stability, and inflation serves as a proxy for macroeconomic stability. A country with unstable inflation rate would harm its citizens by bringing uncertainty into their day to day business transactions, which, ultimately will decrease their income.

I also control for the net ODA amount because HIPC debt relief is not the only help that a country can receive. Many countries receive ODA. This variable is in millions of U.S. dollars. Besides the receipt of foreign aid, I also control for the expenditures in repaying national debt. The variable debtservice captures the percentage of total debt service as a percent of GNI.

Net foreign direct investment, FDI, is a tool to capture inflows of funds and capital from other countries. It is a vehicle to promote productivity and economic growth. The health expenditure variable is the ratio of public health expenditures divided to GDP. Theoretically this ratio should improve the life expectancy and indirectly contribute to the GDP per capita. For geographical characteristics controls, I use the absolute latitude and landlock dummy. The absolute latitude of the country, absLat, takes a value between 0 and 1 , with 1 being further away from the equator. ${ }^{2}$ The landlock variable controls for access to a port that facilitates trade. Table 3.3 to Table 3.6 present the descriptive statistics of all of the variables.

\subsection{Econometric Models}

My goal is to estimate the direct and indirect effects of HIPC membership on real GDP per capita. According to Elhorst (2010), if the OLS model is rejected in favor of Spatial AutoRegressive (SAR) or Spatial Error Model (SEM) then the Spatial Durbin Model (SDM) should be estimated. If the theta $(\theta)$ parameter fails the hypothesis test of $\theta=0$, then SAR should be used. On the other hand, if $\theta+\rho \beta=0$ then the SEM should be used. I ran the Spatial Durbin regression and my models passed the test of having $\rho$ an $\theta$ not equal to zero.

\footnotetext{
${ }^{2}$ Data from article: La Porta, R., Lopez-de-Silanes, F., Shleifer, A.. and Vishny, R. 1999. The Quality of Government. Journal of Law, Economics and Organization, 15(1): 222-279.
} 
The SDM model takes the following form:

$$
\begin{aligned}
& y_{i}=\alpha i_{N}+\rho \Sigma W_{i j} y_{j}+X_{i} \beta+\Sigma W_{i j} X_{i j} \theta+\varepsilon_{i} \\
& \varepsilon_{i} \sim \operatorname{MVN}\left(0, \sigma^{2} I_{n}\right)
\end{aligned}
$$

I find that the thetas, $(\theta)$, and the rhos, $(\rho)$, are not zero; therefore, I will use the SDM model. Nevertheless, I also estimate the SLX model as a robustness check.

$$
\begin{gathered}
y_{i}=\alpha i_{N}+X_{i} \beta+\Sigma W_{i j} X_{i j} \theta+\varepsilon_{i} \\
\varepsilon_{i} \sim M V N\left(0, \sigma^{2} I_{n}\right)
\end{gathered}
$$

Here $n$ is the number of observations, in this case, it is the number of countries. $\mathrm{Y}$ is an $\mathrm{n} \times 1$ vector of observations which contains the dependent variable, real GDP per capita. $\mathrm{X}$ is an $\mathrm{n} \mathrm{x} \mathrm{k}$ matrix of independent variables. $\varepsilon$ is an $\mathrm{n} \mathrm{x}$ vector of independently and identically distributed disturbance, and $\beta$ is a $\mathrm{k} \times 1$ vector of regression parameters. The $\mathrm{W}$ is an $\mathrm{n} \mathrm{x} n$, row normalized, four-nearest-neighbors spatial weight matrix. The spatial weight matrix, W, is of geographic location which is exogeneous to real GDP per capita. Using a nearest-neighbor spatial weight matrix instead of a contiguity spatial weight matrix helps me deal with island countries. Some countries do not have any connected neighbor. $(\theta)$ is a $\mathrm{k} \times 1$ vector of response parameter to the interaction effects of WX.

In terms of interpretations, the SLX model's $\beta$ 's represent the direct effect of X while $\theta$ 's correspond to the indirect (or spillover) effects. Unlike the SLX, the SDM model is a little more complicated because of the $\rho$ term. The $\rho$ is the spatial dependence parameter, and it informs us the feedback effects. Equation 3.3 expresses the SDM model in reduced form.

$$
y_{i}=(I-\rho W)^{-1} \alpha i_{N}+(I-\rho W)^{-1}(X \beta+W X \theta)+(I-\rho W)^{-1} \varepsilon_{i}
$$

When we compute $\partial y / \partial X_{r}$ we get $\left(I_{n}-\rho W\right)^{-1}\left(\beta_{X_{i}}+W \theta_{X_{i}}\right)$. Therefore, $\beta$ is no longer sufficient to measure the impact of the $\mathrm{X}$ variable. To properly interpret the impact of each explanatory variable, we need to look at each variable's direct and indirect effects. 


\subsection{Regression Results}

The spatial autocorrelation parameters, $\rho$ 's are statistically significant in all model variations. The $\rho$ 's range from 0.5 to 0.75 . This translates to similar GDP per capita from country $i$ and its surrounding neighbors. Even when island countries are included, there are significant spillovers effects of the HIPC member variable. Direct effects measure how a change in the explanatory variable in location $i$ can affect the dependent variable at location $i$, plus the feedback effects. Indirect effects $(\theta$ 's $)$ are cumulated over all neighbors of location $i$ to other locations.

For the SDM model, we cannot simply look at the $\beta$ 's and $\theta$ 's because of feedback effects from the $\rho$ 's. Table 3.11 and Table 3.12 list the direct, indirect, and total effects for the SDM models for the 64 countries data set and the 57 countries data set, respectively. Direct effects are statistically significant for HIPC debt relief, and the months. Indirect effects are statistically significant for the HIPC member variable. For the SLX model, direct effects are the $\beta$ 's and indirect effects are the $\theta$ 's.

Out of the three HIPC variables, two of them, HIPCrelief and the HIPC program duration, months, have statistically significant direct, and total effects. HIPCrelief direct effect is -0.00013 , indirect effect is 4e-06, and the total effect is -0.00012 . The OLS coefficient for this model specification is -0.00014. Using HIPC debt relief, OLS and SDM results are similar.

When we use the dummy member variable, results are different. Without the spatial model, we will only see that member has no statistical significance from OLS. However, with the Spatial Durbin Model, the indirect effect is statistically significant at -0.15324 . This represents the spatial spillover effects of being a HIPC member on neighboring countries. The impact is negative. Hence, having a neighbor that is a HIPC country adversely affects one's GDP.

There are several requirements for HIPC countries to complete before they finish the pro- 
gram. Besides maintaining macroeconomic stability, they also need to increase public health expenditures, build more schools, and decrease poverty. These attempts should help increase real GDP per capita. Economic reasons behind the negative effects of HIPC variables could be due to the fact that we use averaged data from 1999 to 2010 for all counties. This includes countries that completed the program long before 2010. Therefore, while some countries saw an increase in real GDP per capita, others may have regressed after they exited the program.

Another surprising result is the statistical insignificance of the variable conflict. According to Murdoch and Sandler (2002), when there is civil war in one country, its neighbors are affected too. My results for conflict has no spillover effects. I infer this difference in outcome due to our difference in time frames and in econometrics approaches. Their study spans from 1961 to 1990, while mine is from 1999 to 2010 . We have no overlap. Also, they test their spillover effects using neighbors that are contiguous, while I use a nearest-neighbor spatial weight matrix. Therefore, in my study, being in a conflict does not have the strong impact that Murdoch and Sandler find in their paper.

Overall, there is consistency in the SLX and the SDM models with regards to impacts of belonging to the HIPC Initiative. HIPCrelief, the relief per capita amount, has a negative effect on the recipient country, with no spillover. Being a HIPC member does not have a statistically significant direct effect on the member country, but it has a negative spillover effect onto surrounding countries. And, the length of time that a country stays in the HIPC program negatively affects its real GDP per capita, but months have no spillover effects.

\subsection{Conclusion}

This paper uses the Spatial Durbin Model to investigate spatial correlations in countries' GDP per capita growth and spillover effects of explanatory variables. I document two key results from the effect of HIPC Initiative debt relief. First, the dependent variable, change in real GDP per capita, is spatially correlated, with $\rho$ values ranging from 0.46 to 0.75 . Second, there are negative spatial spillovers effect of HIPC's membership from country $i$, onto its 
neighbor, country $j$, based on the indirect effect of the explanatory variable, member. 


\subsection{Tables}

Table 3.1: Country List 1

\begin{tabular}{|c|c|c|c|c|}
\hline & Name & Months & HIPC dummy & HIPC aid (millions) \\
\hline 1 & Afghanistan & 31 & 1 & $\$ 1,319$ \\
\hline 2 & Algeria & 0 & 0 & $\$-$ \\
\hline 3 & Andorra & 0 & 0 & $\$-$ \\
\hline 4 & Argentina & 0 & 0 & $\$-$ \\
\hline 5 & Benin & 32 & 1 & $\$ 1,596$ \\
\hline 6 & Bolivia & 16 & 1 & $\$ 4,876$ \\
\hline 7 & Brazil & 0 & 0 & $\$-$ \\
\hline 8 & Burkina Faso & 21 & 1 & $\$ 2,147$ \\
\hline 9 & Burundi & 41 & 1 & $\$ 1,468$ \\
\hline 10 & Cameroon & 66 & 1 & $\$ 6,202$ \\
\hline 11 & Cape Verde & 0 & 0 & $\$-$ \\
\hline 12 & Central African Republic & 21 & 1 & $\$ 1,105$ \\
\hline 13 & Chad & 117 & 1 & $\$ 260$ \\
\hline 14 & Chile & 0 & 0 & $\$-$ \\
\hline 15 & Comoros & 7 & 1 & $\$ 136$ \\
\hline 16 & Congo, Dem Rep & 84 & 1 & $\$ 16,273$ \\
\hline 17 & Congo, Republic of & 46 & 1 & $\$ 1,942$ \\
\hline 18 & Costa Rica & 0 & 0 & $\$-$ \\
\hline 19 & Cote d'Ivoire & 40 & 1 & $\$ 3,415$ \\
\hline 20 & Dominican Republic & 0 & 0 & $\$-$ \\
\hline 21 & Egypt & 0 & 0 & $\$-$ \\
\hline 22 & El Salvador & 0 & 0 & $\$-$ \\
\hline 23 & Eritrea & 0 & 0 & $\$-$ \\
\hline 24 & Ethiopia & 29 & 1 & $\$ 6,555$ \\
\hline 25 & Gabon & 0 & 0 & $\$-$ \\
\hline 26 & Gambia & 84 & 1 & $\$ 495$ \\
\hline 27 & Ghana & 29 & 1 & $\$ 7,368$ \\
\hline 28 & Guatemala & 0 & 0 & $\$-$ \\
\hline 29 & Guinea & 143 & 1 & $\$ 800$ \\
\hline 30 & Guinea-Bissau & 122 & 1 & $\$ 790$ \\
\hline 31 & Guyana & 37 & 1 & $\$ 2,061$ \\
\hline 32 & Haiti & 31 & 1 & $\$ 1,172$ \\
\hline 33 & Honduras & 58 & 1 & $\$ 3,714$ \\
\hline 34 & Kenya & 0 & 0 & $\$-$ \\
\hline 35 & Liberia & 27 & 1 & $\$ 4,866$ \\
\hline
\end{tabular}


Table 3.2: Country List 2

\begin{tabular}{|c|c|c|c|c|}
\hline & Name & Months & HIPC dummy & HIPC aid (millions) \\
\hline 36 & Libya & 0 & 0 & $\$-$ \\
\hline 37 & Madagascar & 47 & 1 & $\$ 4,293$ \\
\hline 38 & Malawi & 69 & 1 & $\$ 3,205$ \\
\hline 39 & Mali & 30 & 1 & $\$ 2,887$ \\
\hline 40 & Mauritania & 28 & 1 & $\$ 1,983$ \\
\hline 41 & Mauritius & 0 & 0 & $\$-$ \\
\hline 42 & Mozambique & 17 & 1 & $\$ 6,332$ \\
\hline 43 & Namibia & 0 & 0 & $\$-$ \\
\hline 44 & Nicaragua & 38 & 1 & $\$ 6,404$ \\
\hline 45 & Niger & 41 & 1 & $\$ 2,252$ \\
\hline 46 & Nigeria & 0 & 0 & $\$-$ \\
\hline 47 & Pakistan & 0 & 0 & $\$-$ \\
\hline 48 & Paraguay & 0 & 0 & $\$-$ \\
\hline 49 & Peru & 0 & 0 & $\$-$ \\
\hline 50 & Rwanda & 53 & 1 & $\$ 1,827$ \\
\hline 51 & Sao Tome and Principe & 76 & 1 & $\$ 333$ \\
\hline 52 & Senegal & 47 & 1 & $\$ 3,320$ \\
\hline 53 & Sierra Leone & 58 & 1 & $\$ 1,659$ \\
\hline 54 & South Africa & 0 & 0 & $\$-$ \\
\hline 55 & Sudan & 0 & 0 & $\$-$ \\
\hline 56 & Suriname & 0 & 0 & $\$-$ \\
\hline 57 & Tajikistan & 0 & 0 & $\$-$ \\
\hline 58 & Tanzania & 19 & 1 & $\$ 6,810$ \\
\hline 59 & Togo & 25 & 1 & $\$ 360$ \\
\hline 60 & Turkmanistan & 0 & 0 & $\$-$ \\
\hline 61 & Uganda & 3 & 1 & $\$ 5,443$ \\
\hline 62 & Venezuela & 0 & 0 & $\$-$ \\
\hline 63 & Zambia & 53 & 1 & $\$ 6,647$ \\
\hline 64 & Zimbabwe & 0 & 0 & $\$-$ \\
\hline
\end{tabular}


Table 3.3: Descriptive Statistics - 63 countries

\begin{tabular}{lcccccc}
\hline \hline Statistic & $\mathrm{N}$ & Mean & St. Dev. & Min & Median & Max \\
\hline HIPCrelief & 63 & 257.551 & 488.434 & 0.000 & 86.894 & $2,672.256$ \\
member & 63 & 0.556 & 0.501 & 0 & 1 & 1 \\
months & 63 & 26.857 & 33.475 & 0 & 19 & 143 \\
FDI & 63 & 4.014 & 4.119 & -5.739 & 2.845 & 22.140 \\
inflation & 63 & 10.932 & 12.657 & 1.426 & 8.481 & 98.294 \\
oda & 63 & 608.341 & 660.418 & 22.967 & 379.579 & $3,096.562$ \\
ROL & 63 & -0.730 & 0.615 & -1.828 & -0.738 & 1.269 \\
polity & 63 & -1.693 & 14.685 & -65.273 & 1.000 & 10.000 \\
conflict & 63 & 0.413 & 0.496 & 0 & 0 & 1 \\
Health & 63 & 2.553 & 1.131 & 0.004 & 2.435 & 5.869 \\
debtservice & 63 & 3.785 & 3.391 & 0.090 & 3.062 & 23.175 \\
landlock & 63 & 0.286 & 0.455 & 0 & 0 & 1 \\
iRGDPpc & 63 & $2,812.417$ & $3,079.963$ & 211.944 & $1,311.017$ & $11,747.240$ \\
nRGDPpc & 63 & $4,211.711$ & $4,404.282$ & 342.704 & $1,951.369$ & $16,632.850$ \\
absLat & 63 & 0.161 & 0.107 & 0.000 & 0.150 & 0.444 \\
lat & 63 & 4.456 & 17.280 & -38.416 & 7.947 & 38.970 \\
long & 63 & -3.621 & 45.448 & -90.231 & 6.613 & 71.276 \\
& & & & & &
\end{tabular}

Table 3.4: Descriptive Statistics - 56 countries

\begin{tabular}{lcccccc}
\hline \hline Statistic & $\mathrm{N}$ & Mean & St. Dev. & Min & Median & Max \\
\hline HIPCrelief & 56 & 242.003 & 449.765 & 0.000 & 74.755 & $2,672.256$ \\
member & 56 & 0.554 & 0.502 & 0 & 1 & 1 \\
months & 56 & 27.339 & 34.129 & 0 & 20 & 143 \\
FDI & 56 & 3.874 & 4.024 & -5.739 & 2.790 & 22.140 \\
inflation & 56 & 11.210 & 13.306 & 2.100 & 8.351 & 98.294 \\
oda & 56 & 652.912 & 680.928 & 22.967 & 382.643 & $3,096.562$ \\
ROL & 56 & -0.770 & 0.577 & -1.828 & -0.765 & 1.269 \\
polity & 56 & -2.216 & 15.057 & -65.273 & 0.409 & 10.000 \\
conflict & 56 & 0.446 & 0.502 & 0 & 0 & 1 \\
Health & 56 & 2.563 & 1.164 & 0.004 & 2.436 & 5.869 \\
debtservice & 56 & 3.935 & 3.554 & 0.090 & 3.131 & 23.175 \\
landlock & 56 & 0.321 & 0.471 & 0 & 0 & 1 \\
iRGDPpc & 56 & $2,805.027$ & $3,109.481$ & 211.944 & $1,316.978$ & $11,747.240$ \\
nRGDPpc & 56 & $4,194.789$ & $4,413.557$ & 342.704 & $1,972.438$ & $16,632.850$ \\
absLat & 56 & 0.161 & 0.110 & 0.000 & 0.148 & 0.444 \\
lat & 56 & 4.961 & 17.326 & -38.416 & 8.204 & 38.970 \\
long & 56 & -3.868 & 44.690 & -90.231 & 5.199 & 71.276 \\
\hline
\end{tabular}




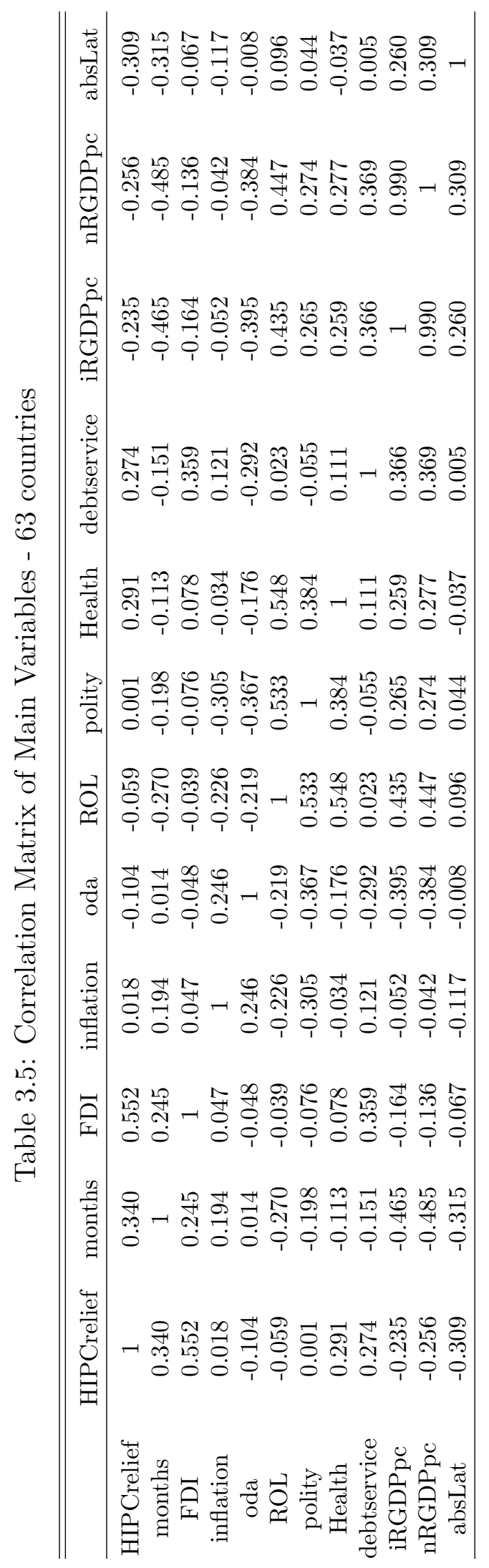




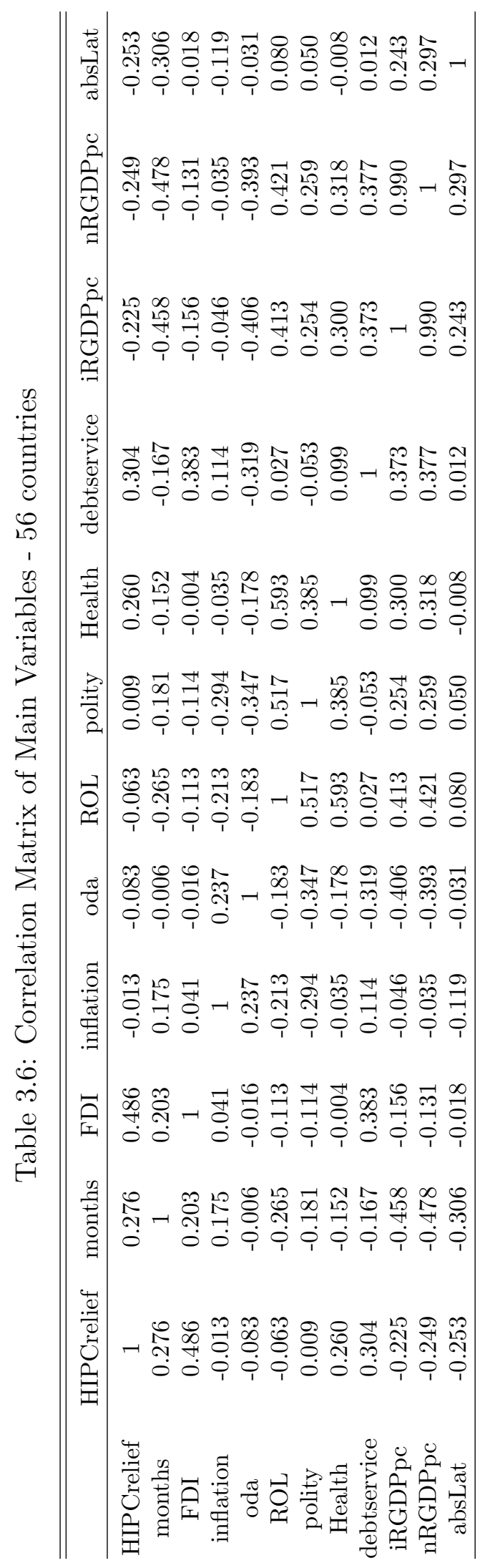


Table 3.7: OLS Regression Results: 63 Countries Data Set

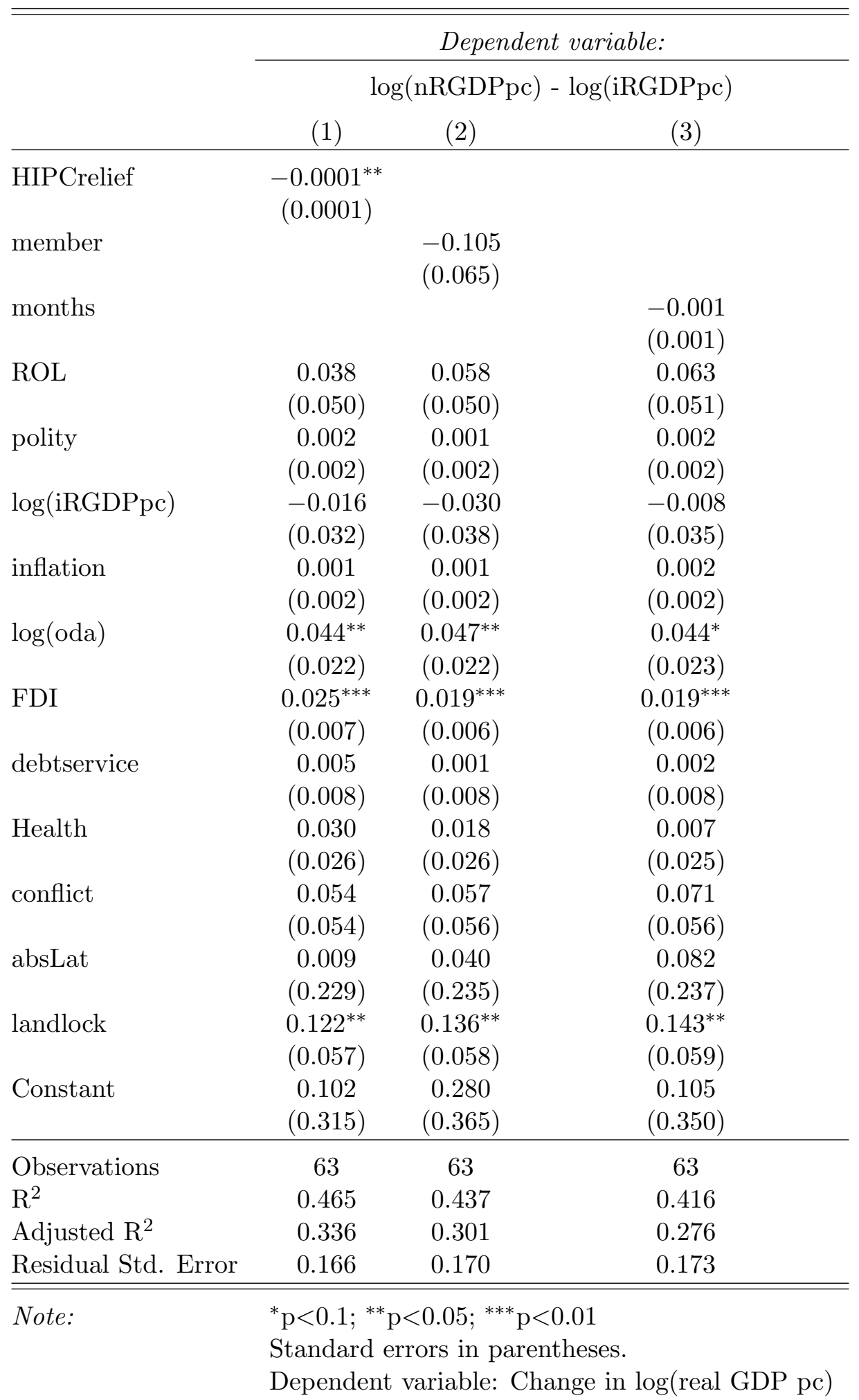


Table 3.8: OLS Regression Results: 56 Countries Data Set

\begin{tabular}{|c|c|c|c|}
\hline & \multicolumn{3}{|c|}{ Dependent variable: } \\
\hline & \multicolumn{3}{|c|}{$\log (\mathrm{nRGDPpc})-\log (\mathrm{iRGDPpc})$} \\
\hline & $(1)$ & $(2)$ & $(3)$ \\
\hline HIPCrelief & $\begin{array}{c}-0.0002^{* *} \\
(0.0001)\end{array}$ & & \\
\hline member & & $\begin{array}{c}-0.073 \\
(0.071)\end{array}$ & \\
\hline months & & & $\begin{array}{l}-0.001 \\
(0.001)\end{array}$ \\
\hline ROL & $\begin{array}{c}0.011 \\
(0.058)\end{array}$ & $\begin{array}{c}0.046 \\
(0.058)\end{array}$ & $\begin{array}{c}0.046 \\
(0.059)\end{array}$ \\
\hline polity & $\begin{array}{c}0.002 \\
(0.002)\end{array}$ & $\begin{array}{c}0.001 \\
(0.002)\end{array}$ & $\begin{array}{c}0.001 \\
(0.002)\end{array}$ \\
\hline $\log (\mathrm{iRGDPpc})$ & $\begin{array}{l}-0.027 \\
(0.035)\end{array}$ & $\begin{array}{l}-0.028 \\
(0.041)\end{array}$ & $\begin{array}{l}-0.015 \\
(0.038)\end{array}$ \\
\hline inflation & $\begin{array}{c}0.001 \\
(0.002)\end{array}$ & $\begin{array}{c}0.001 \\
(0.002)\end{array}$ & $\begin{array}{c}0.002 \\
(0.002)\end{array}$ \\
\hline $\log ($ oda $)$ & $\begin{array}{l}0.055^{* *} \\
(0.024)\end{array}$ & $\begin{array}{l}0.053^{* *} \\
(0.025)\end{array}$ & $\begin{array}{l}0.050^{*} \\
(0.027)\end{array}$ \\
\hline FDI & $\begin{array}{c}0.022^{* * *} \\
(0.007)\end{array}$ & $\begin{array}{l}0.018^{* *} \\
(0.007)\end{array}$ & $\begin{array}{l}0.016^{* *} \\
(0.007)\end{array}$ \\
\hline debtservice & $\begin{array}{c}0.007 \\
(0.008)\end{array}$ & $\begin{array}{c}0.002 \\
(0.009)\end{array}$ & $\begin{array}{c}0.002 \\
(0.009)\end{array}$ \\
\hline Health & $\begin{array}{c}0.038 \\
(0.028)\end{array}$ & $\begin{array}{c}0.020 \\
(0.028)\end{array}$ & $\begin{array}{c}0.012 \\
(0.027)\end{array}$ \\
\hline conflict & $\begin{array}{c}0.062 \\
(0.056)\end{array}$ & $\begin{array}{c}0.069 \\
(0.059)\end{array}$ & $\begin{array}{c}0.079 \\
(0.058)\end{array}$ \\
\hline absLat & $\begin{array}{c}0.126 \\
(0.233)\end{array}$ & $\begin{array}{c}0.147 \\
(0.248)\end{array}$ & $\begin{array}{c}0.181 \\
(0.247)\end{array}$ \\
\hline landlock & $\begin{array}{c}0.088 \\
(0.060)\end{array}$ & $\begin{array}{c}0.114^{*} \\
(0.062)\end{array}$ & $\begin{array}{c}0.115^{*} \\
(0.063)\end{array}$ \\
\hline Constant & $\begin{array}{c}0.084 \\
(0.351) \\
\end{array}$ & $\begin{array}{c}0.198 \\
(0.417) \\
\end{array}$ & $\begin{array}{c}0.094 \\
(0.408) \\
\end{array}$ \\
\hline Observations & 56 & 56 & 56 \\
\hline $\mathrm{R}^{2}$ & 0.481 & 0.429 & 0.420 \\
\hline Adjusted $\mathrm{R}^{2}$ & 0.337 & 0.270 & 0.258 \\
\hline Residual Std. Error & 0.165 & 0.173 & 0.174 \\
\hline Note: & $\begin{array}{l}{ }^{*} \mathrm{p}<0.1 ;{ }^{* *} \\
\text { Standard } \\
\text { Dependen }\end{array}$ & $\begin{array}{l}0.05 ; \\
\text { ors in } \\
\text { riable }\end{array}$ & $\log ($ real GDP pc) \\
\hline
\end{tabular}


Table 3.9: SLX Regression Results: 63 Countries Data Set

\begin{tabular}{|c|c|c|c|}
\hline & \multicolumn{3}{|c|}{ Dependent variable: } \\
\hline & \multicolumn{3}{|c|}{$\log (\mathrm{nRGDPpc})-\log (\mathrm{iRGDPpc})$} \\
\hline & $(1)$ & $(2)$ & $(3)$ \\
\hline HIPCrelief & $\begin{array}{c}-0.0002^{* *} \\
(0.0001)\end{array}$ & & \\
\hline member & & $\begin{array}{l}-0.104 \\
(0.069)\end{array}$ & \\
\hline months & & & $\begin{array}{c}-0.002^{* *} \\
(0.001)\end{array}$ \\
\hline ROL & $\begin{array}{l}-0.002 \\
(0.052)\end{array}$ & $\begin{array}{c}0.014 \\
(0.051)\end{array}$ & $\begin{array}{c}0.003 \\
(0.049)\end{array}$ \\
\hline polity & $\begin{array}{c}0.001 \\
(0.002)\end{array}$ & $\begin{array}{l}-0.001 \\
(0.002)\end{array}$ & $\begin{array}{c}0.001 \\
(0.002)\end{array}$ \\
\hline $\log (\mathrm{iRGDPpc})$ & $\begin{array}{l}-0.004 \\
(0.037)\end{array}$ & $\begin{array}{l}-0.017 \\
(0.040)\end{array}$ & $\begin{array}{l}-0.036 \\
(0.038)\end{array}$ \\
\hline inflation & $\begin{array}{c}-0.0002 \\
(0.002)\end{array}$ & $\begin{array}{c}-0.0005 \\
(0.002)\end{array}$ & $\begin{array}{c}0.001 \\
(0.002)\end{array}$ \\
\hline $\log ($ oda $)$ & $\begin{array}{c}0.002 \\
(0.028)\end{array}$ & $\begin{array}{l}-0.018 \\
(0.028)\end{array}$ & $\begin{array}{l}-0.027 \\
(0.026)\end{array}$ \\
\hline FDI & $\begin{array}{c}0.015^{* *} \\
(0.007)\end{array}$ & $\begin{array}{l}0.013^{*} \\
(0.006)\end{array}$ & $\begin{array}{c}0.014^{* *} \\
(0.006)\end{array}$ \\
\hline debtservice & $\begin{array}{l}0.0004 \\
(0.008)\end{array}$ & $\begin{array}{l}-0.004 \\
(0.008)\end{array}$ & $\begin{array}{l}-0.006 \\
(0.008)\end{array}$ \\
\hline Health & $\begin{array}{c}0.063^{* *} \\
(0.029)\end{array}$ & $\begin{array}{c}0.042 \\
(0.028)\end{array}$ & $\begin{array}{l}0.051^{*} \\
(0.026)\end{array}$ \\
\hline conflict & $\begin{array}{c}0.036 \\
(0.055)\end{array}$ & $\begin{array}{c}0.051 \\
(0.055)\end{array}$ & $\begin{array}{c}0.049 \\
(0.052)\end{array}$ \\
\hline absLat & $\begin{array}{l}-0.600 \\
(0.485)\end{array}$ & $\begin{array}{l}-0.198 \\
(0.465)\end{array}$ & $\begin{array}{l}-0.167 \\
(0.448)\end{array}$ \\
\hline landlock & $\begin{array}{c}0.172^{* * *} \\
(0.062)\end{array}$ & $\begin{array}{c}0.197^{* * *} \\
(0.059)\end{array}$ & $\begin{array}{c}0.195^{* * *} \\
(0.059)\end{array}$ \\
\hline WX.HIPCrelief & $\begin{array}{l}-0.0001 \\
(0.0002)\end{array}$ & & \\
\hline WX.member & & $\begin{array}{c}-0.259^{*} \\
(0.140)\end{array}$ & \\
\hline WX.months & & & $\begin{array}{c}-0.003^{*} \\
(0.002)\end{array}$ \\
\hline WX.ROL & $\begin{array}{l}-0.188 \\
(0.139)\end{array}$ & $\begin{array}{l}-0.102 \\
(0.138)\end{array}$ & $\begin{array}{c}-0.244^{*} \\
(0.128)\end{array}$ \\
\hline WX.polity & $\begin{array}{l}-0.003 \\
(0.006)\end{array}$ & $\begin{array}{l}-0.006 \\
(0.005)\end{array}$ & $\begin{array}{l}-0.002 \\
(0.005)\end{array}$ \\
\hline WX.log(iRGDPpc) & $\begin{array}{l}-0.083 \\
(0.065)\end{array}$ & $\begin{array}{c}-0.195^{* *} \\
(0.076)\end{array}$ & $\begin{array}{c}-0.213^{* * *} \\
(0.074)\end{array}$ \\
\hline WX.inflation & $\begin{array}{c}-0.010^{*} \\
(0.005)\end{array}$ & $\begin{array}{c}-0.014^{* * *} \\
(0.005)\end{array}$ & $\begin{array}{c}-0.016^{* * *} \\
(0.005)\end{array}$ \\
\hline WX.log(oda) & $\begin{array}{c}-0.165^{* *} \\
(0.073)\end{array}$ & $\begin{array}{c}-0.233^{* * *} \\
(0.071)\end{array}$ & $\begin{array}{c}-0.245^{* * *} \\
(0.069)\end{array}$ \\
\hline WX.FDI & $\begin{array}{l}-0.013 \\
(0.016)\end{array}$ & $\begin{array}{l}-0.005 \\
(0.016)\end{array}$ & $\begin{array}{l}-0.002 \\
(0.016)\end{array}$ \\
\hline WX.debtservice & $\begin{array}{l}-0.005 \\
(0.022)\end{array}$ & $\begin{array}{l}-0.009 \\
(0.020)\end{array}$ & $\begin{array}{c}0.011 \\
(0.021)\end{array}$ \\
\hline WX.Health & $\begin{array}{l}-0.005 \\
(0.052)\end{array}$ & $\begin{array}{l}-0.012 \\
(0.051)\end{array}$ & $\begin{array}{c}0.017 \\
(0.047)\end{array}$ \\
\hline WX.conflict & $\begin{array}{l}-0.019 \\
(0.143)\end{array}$ & $\begin{array}{l}-0.182 \\
(0.144)\end{array}$ & $\begin{array}{c}0.017 \\
(0.134)\end{array}$ \\
\hline WX.absLat & $\begin{array}{c}0.517 \\
(0.701)\end{array}$ & $\begin{array}{l}-0.380 \\
(0.735)\end{array}$ & $\begin{array}{l}-0.218 \\
(0.670)\end{array}$ \\
\hline WX.landlock & $\begin{array}{c}0.171 \\
(0.146)\end{array}$ & $\begin{array}{c}0.161 \\
(0.140)\end{array}$ & $\begin{array}{c}0.082 \\
(0.148)\end{array}$ \\
\hline Constant & $\begin{array}{l}1.816^{* *} \\
(0.834) \\
\end{array}$ & $\begin{array}{c}3.721^{* * *} \\
(1.098) \\
\end{array}$ & $\begin{array}{c}3.700^{* * *} \\
(1.007)\end{array}$ \\
\hline Observations & 63 & 63 & 63 \\
\hline $\mathrm{R}^{2}$ & 0.648 & 0.660 & 0.686 \\
\hline Adjusted $\mathrm{R}^{2}$ & 0.425 & 0.445 & 0.487 \\
\hline Residual Std. Error & 0.154 & 0.152 & 0.146 \\
\hline
\end{tabular}


Table 3.10: SLX Regression Results: 56 Countries Data Set

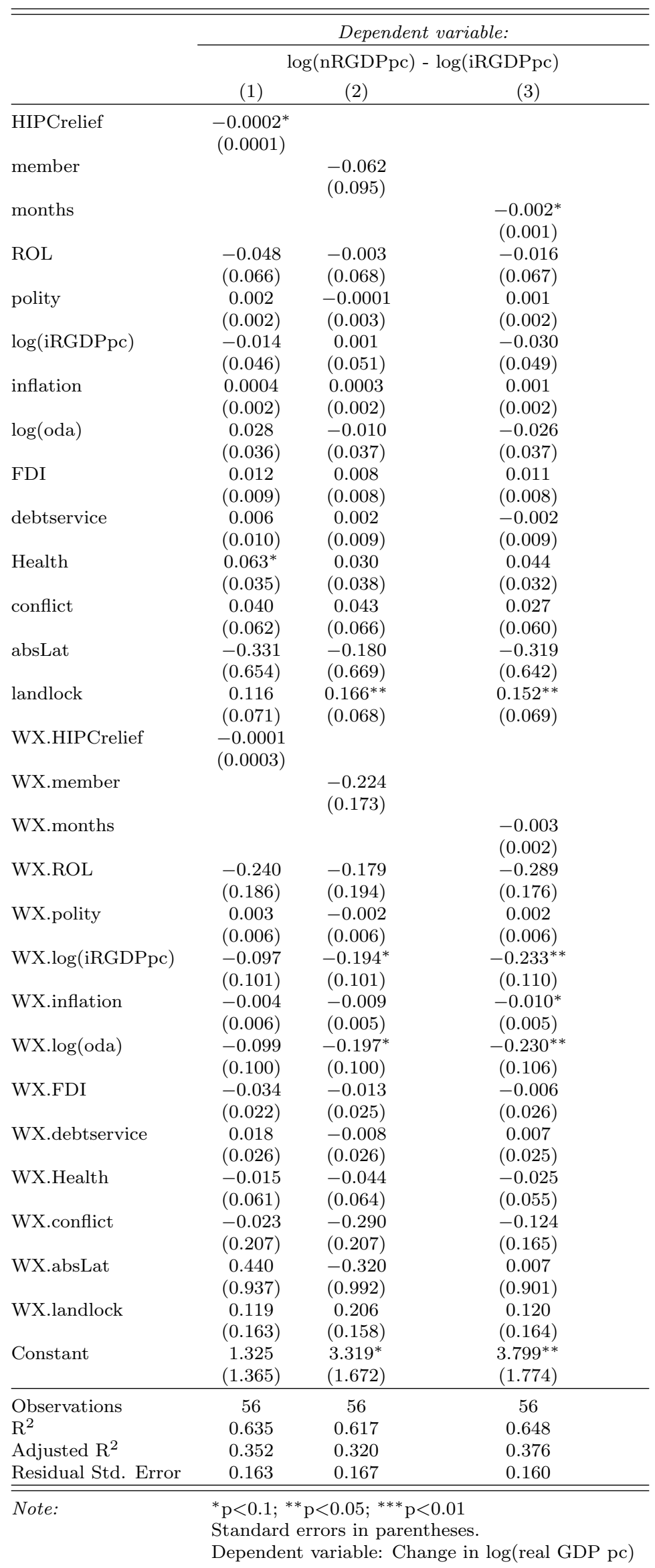




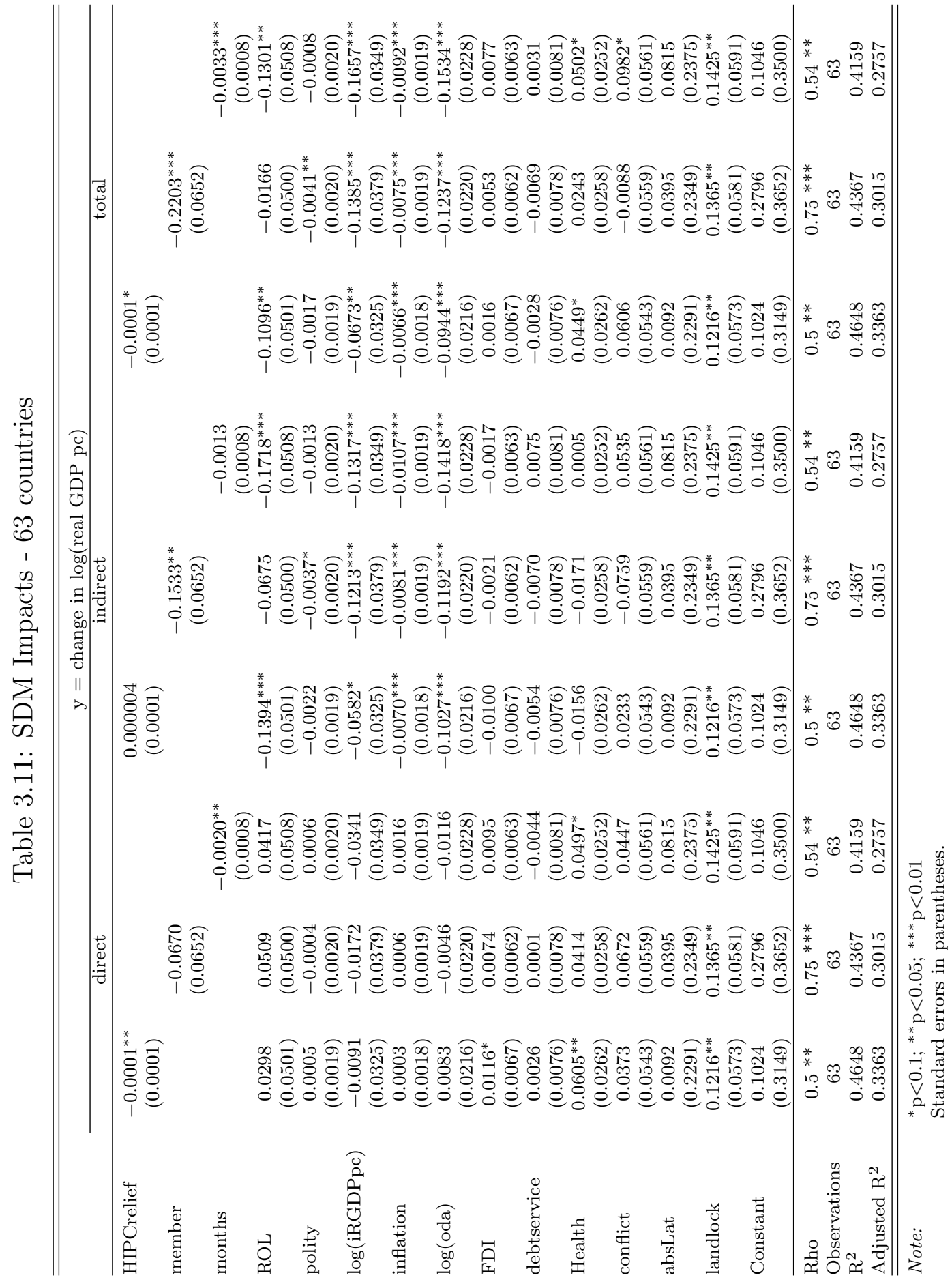




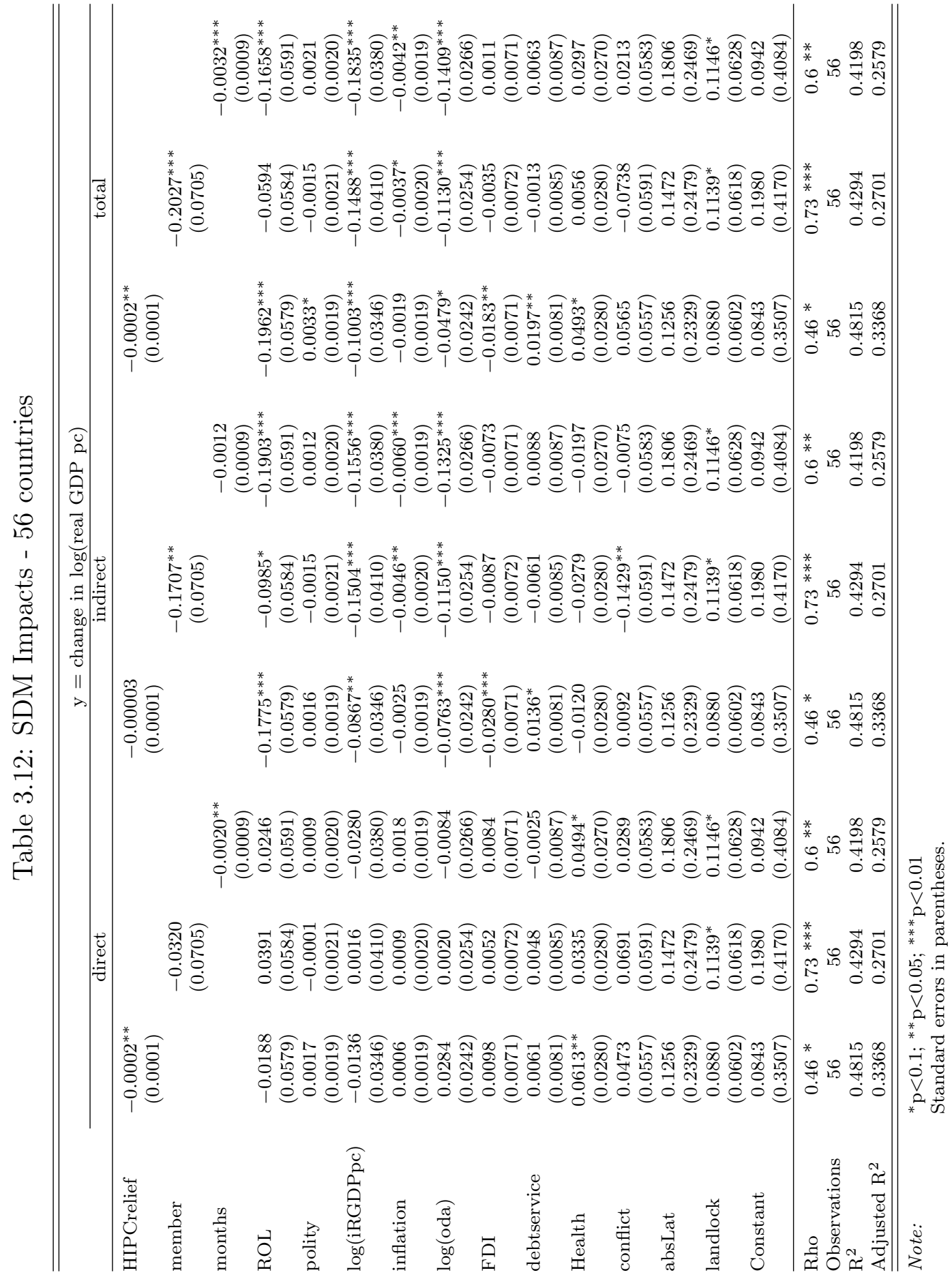




\section{Chapter 4}

\section{Can Foreign Aid Motivate}

\section{Institutional Reform?}

\section{An Evaluation of the HIPC Initiative}

\subsection{Introduction}

In the 1970s Peter Bauer (1972) was a rarity among economists in questioning the desirability and effectiveness of foreign aid programs. Mainstream development experts discounted his perspectives. Condescendingly, Walt Rostow (1990, p. 386) alleged "a gap between the market economist and the wider but somewhat casual commentator on the human condition"; and that "Bauer seemed most comfortable as a neoclassical gadfly on the rump of what he regarded as the international liberal establishment." More than two decades later, Boone (1996) empirically vindicated Bauer's views. He demonstrated that cross-country data did not evidence a positive relationship between aid and economic growth in poor economies. Bauer's views suddenly became respectable among mainstream economists.

Of course, respectable did not equate to uncontroversial. Proponents of foreign aid did not throw in the towel. Notably, Burnside and Dollar $(2000,2004)$ were able to report a positive aid-growth relationship based on cross-country data when the relationship was estimated conditional on recipients having good policy environments (e.g., low rates of inflation; 
liberal trade policies). However, Easterly (2003) and Easterly et al. (2004) demonstrated that those results were not robust to small changes in the time period and the countries included in the sample. Rajan and Subramanian (2008) also failed to report that a positive aid-growth effect even for recipients with good policy environments. Brumm (2003) went further and argued that if long-run averages rather than panel data are employed, then both the Burnside and Dollar and Easterly et al. samples indicate a significantly negative effect of aid on growth; regardless of the policy environment. ${ }^{1}$

A number of political economy concerns are associated with the provision of foreign aid to developing economies. These concerns suggest that foreign aid is likely to have deleterious effects on recipients' institutional quality. North and Thomas (1973) and North (1990) were seminal in focusing researchers' attentions on the role of institutional quality in economic development. They emphasized the importance of the "rules of the game" and how they shape human action, channeling it towards relatively productive or unproductive endeavors. Studies by Knack and Keefer (1995), Barro (1996), Hall and Jones (1999), Acemoglu et al. (2001, 2002), Rodrick et al. (2004), and Acemoglu and Johnson (2005) subsequently reported evidence of a robust, positive relationship between the strength of property rights and the rule-of-law on the one hand and income levels and growth on the other. A large empirical literature now supports the consensus view that institutions rule (Rodrick et al., 2004).

If aid is, at best, effective in promoting economic growth in good policy environments, then the potential for aid flows to cause deteriorations in institutional quality is doubly troubling. Aid may tend to degrade the very institutional arrangements that are necessary for it to be potentially helpful. Moreover, the cold hard fact is that countries tend to be poor because they have poor institutional quality in the first place. This suggests that to be effective aid must be conditional on improvements in the policies and institutions of recipients.

\footnotetext{
${ }^{1}$ Doucouliagos and Paldam $(2008,2009)$ survey studies of unconditional and conditional effectiveness. Their meta-analyses do not evidence aid's effectiveness, nor of the conditionality of its effectiveness on policy.
} 
In this paper we review the political economy concerns associated with foreign aid and the existing evidence suggesting that they are important. These concerns suggest that aid is likely to have harmful effects on recipients' institutions; likewise, that attempts to give aid conditional on reforms are unlikely to succeed. Then we turn our attention to a recent multilateral aid program that is explicitly designed to foster improvements in policies and institutional quality and to monitor the progress of those improvements. Established in 1996, the Heavily Indebted Poor Country (HIPC) Initiative aims to help low-income countries (LICs) burdened with large amounts of debt achieve robust economic growth and development. The HIPC Initiative represents the IMF's and World Bank's best attempt to acknowledge and overcome the political economy concerns associated with foreign aid. To date is has provided over $\$ 76$ billion in debt relief conditional (at least nominally) on recipient reforms.

We present evidence that the HIPC Initiative's track record has been lackluster. Examining measures of economic and political institutional quality, about one third of countries experienced decreases while participating in the Initiative. For participating countries that experienced increases in these measures, in almost every single case the increases were negligible. Furthermore, we present the results of regressions that relate changes in the institutional measures to HIPC Initiative aid. The partial correlations between aid and institutional change are never statistically significant. When the point estimates are positive they suggest miniscule effects. The best shot by the IMF and World Bank to link foreign aid to policy and institutional reforms has failed to overcome the perverse incentives that aid creates.

\subsection{Foreign Aid and Institutional Quality}

The ostensible motivation for developed economies and international agencies to give foreign aid is twofold. First and foremost, donors desire that poor economies do not remain poor. Being poor is characterized by a lack of income and wealth; rich economies can fill 
the gap by transferring some of their income and wealth to the poor. Second, poor countries must use the aid to not only raise current consumption levels, but to undertake investments that lead to sustained growth. Who better to advise about and orchestrate those investments than the experts from demonstrated economic development successes, i.e., the rich economies?

Of course, the reality of foreign aid is anything but straightforward. Foreign aid is not delivered via a helicopter drop. Rather, it is typically delivered through a recipient government. Recipient politicians respond to incentives associated with acquiring the aid. Then the recipient government must disburse the aid. Recipient politicians respond to incentives associated with disbursing the aid in particular ways; other individuals in the recipient economy respond to incentives associated with becoming the particular ways in which the aid is disbursed. There is a complex political economy of aid where the ultimate patterns of disbursement are a function of the institutions within in which recipient agents operate. Generally, then, foreign aid can create incentives for those agents to emphasize certain institutions that allow them to benefit from the aid, and to change or ignore (and therefore weaken) those institutions that hinder their efforts to benefit.

Sadly, the heyday of foreign aid programs was characterized by an ignorance of these political economy concerns. As Leeson (2008, p. 40) noted:

In the years preceding WWII, economic development as a field of economic study did not exist in ant meaningful sense. [...] On the contrary, from the classical political economists, such as Smith (1776) and J. S. Mill (1848), to their intellectual successors, such as Ludwig von Mises (1949) and F. A. Hayek (1960), the causes and consequences of the wealth and poverty of nations were simply part of the unified social science of political economy.

But this subsequently changed. Aside from a handful of luminaries such as Peter Bauer, economists and policymakers began to lose sight of the political economy of foreign aid. The 
rise of the OECD, the IMF, the World Bank, and the so-called "development community" was associated with the proliferation of technocratic development experts. These experts believed that a centrally planned "national economic development policy" embodying "an overall integrated national plan" was a sine qua non for achieving sustained economic growth (Bauer, 1969). ${ }^{2}$ They turned a blind eye to the fact that the potential for aid to help (or harm) depended on the incentives faced by agents in both donor and recipient countries, as well as their ability to overcome the information problems associated with the allocation and utilization of the aid (Williamson, 2010).

Within the political economy of foreign aid there are a number of specific mechanisms through which aid can be linked to deteriorations in institutional quality. For example, if we conceive of a government as a revenue-maximizing Leviathan (Brennan and Buchanan, 1980) then opportunities for foreign aid can make it less responsive and accountable to its citizens. For a given level of spending, foreign aid leaves a recipient government less reliant on tax revenues. If politicians believe that they can turn to foreign aid when its citizens become less willing to pay taxes, then they will act with less concern for their reactions. Alternatively, citizens will support what are ultimately ill-advised government expenditures when, in the short-run, they are not financed by their tax dollars. Foreign aid can soften a recipient government's budget constraint and also make it more independent of its citizens' preferences and budget constraints.

Aid flows also represent windfalls that politicians can choose to disburse through specific channels and towards specific individuals or firms. Aid creates means by which politicians can secure their power and/or extract bribes or favors. Furthermore, individuals and firms may perceive the rewards to joining the competition for aid disbursements to be greater than those associated with productive activities (Baumol, 1990). Djankov et al. (2008) has drawn an analogy between aid flows and the sort of subterranean resources associated with resource curses (Auty, 1990; Sachs and Warner, 1999 \& 2001). Both represent "point-source" flows of rents around which well-defined competition can emerge. The wasteful competition can

\footnotetext{
${ }^{2}$ Bauer pulls the specific "national economic development policy" from Myrdal (1956, p. 63).
} 
corrupt a recipient economy's institutions. Svensson (2000) analyzed this sort of competition in a game theoretic framework. He modeled aid as a common-pool resource that can either be allocated by the government towards public goods provision or appropriated by private agents for consumption. Svensson's analysis highlights the twofold costs associated with the competition for aid disbursements. First, efforts by private agents to appropriate aid are redundant and therefore wasteful. Second, the efforts to appropriate aid are undertaken at the cost of productive activities.

A growing literature has provided empirical evidence demonstrating the links between foreign aid flows and decreases in institutional quality. Svenson (2000) reported that aid flows are associated with higher levels of corruption in government. Rajan and Sabramanian (2007) found that aid flows are correlated with reductions in countries' International country Risk Guide scores; Brutigam and Knack (2004) reported similar results for a sample of Sub-Saharan African countries. Kalyvitis and Vlachaki (2012) found that aid discouraged recipients from undertaking democratic reforms and Djankov et al. (2008) reported that higher aid flows were associated with actual deteriorations in recipients' political institutions. Powell and Ryan (2006) and Heckelman and Knack (2008) found similar effects on economic institutions. More recently, Young and Sheehan (2014) reported that aid has negative effects on a number of political and economic institutional quality measures based on a panel of 116 countries during 1970-2010. Regarding economic institutions, Young and Sheehan found that a recipient's legal system, the security of its property rights, and its openness to trade are particularly affected.

\subsection{The HIPC Initiative}

Established in 1996 by the IMF and World Bank, the Heavily Indebted Poor Country (HIPC) Initiative aims to help low-income countries (LICs) burdened with high debt to achieve robust economic growth and development. The HIPC Initiative calls for the voluntary provision of debt relief by a participating country's creditors. These creditors can be other countries, international organizations, or commercial interests. In 2005 the Multilat- 
eral Debt Relief Initiative (MDRI) supplemented the HIPC Initiative. The MDRI provides, for countries successfully completing the HIPC Initiative, full relief on debts to the IMF, World Bank, and the African Development Fund. To date, 36 countries have participated in the HIPC Initiative and, collectively, their debt service has declined by about 1.8 percentage points of GDP. ${ }^{3}$

Built into the HIPC Initiative is an expectation that participants pursue policy and institutional reforms that decrease the risk of relapses into high debt levels and increase the likelihood of sustained growth. Participating countries are required to produce a Poverty Reduction Strategy Paper (PRSP) to be approved by the IMF and World Bank. Progress reports must be submitted and the PRSP must be satisfactorily implemented for at least one year. Upon approval ("decision point") countries receive interim debt relief in advance of the "completion point" when irrevocable debt stock relief is granted. As of May 2015, of 39 countries eligible for the Initiative, 36 had participated in the Initiative and reached the completion point. ${ }^{4}$ By the last estimate (net present value as of 2013) about $\$ 76$ billion of debt relief had been granted (IDA \& IMF, 2013).

Debt relief is, of course, a very particular type of foreign aid. Cassimon and van Campenhout (2007) have argued that debt relief is a type of multilateral aid that is relatively effective. Regardless of the veracity of that claim, in this paper we are interested in the HIPC Initiative in because of the conditions that are imposed on Initiative participants. ${ }^{5}$ Those conditions represent "a heavy and diversified portfolio of conditionality, including not only broad macroeconomic and structural reform [...] through the conventional IMF program, but

\footnotetext{
${ }^{3}$ See: https://www.imf.org/external/np/exr/facts/hipc.htm (last accessed May 15, 2015).

${ }^{4}$ See: $\quad$ https://www.imf.org/external/np/exr/facts/hipc.htm (last accessed May 15, 2015). Chad reached the completion point most recently as of May 13, 2015: http://www.imf.org/external/pubs/ft/scr/2015/cr15124.pdf (last accessed May 15, 2015).

${ }^{5}$ Cassimon and van Campenhout (2007) employ a very non-standard approach relative to most of the empirical foreign aid literature. They study a panel of annual data from on 28 HIPC countries, 1991-2004, in a vector autoregression (VAR) with 7 variables. Aside from debt relief, the remaining 6 variables are all government expenditure, revenue, and borrowing variables. Aside from country fixed effects, there are no other control variables. There is no explicit link from the expenditure, revenue, and borrowing variables to other economic outcomes (e.g., income growth). Therefore, as an aside, there is good reason to question the veracity of their claim.
} 
also with broad poverty focus through the PRSP" (Cassimon and van Campenhout, 2007, p. 747). Participating countries are determined to have reached their completion points when they "maintain macroeconomic stability under a PRGF-[Poverty Reduction and Growth Facility]-supported program, carry out key structural and social reforms, and implement a PRSP for one year[.]" 6

Consider Togo as an example. Togo reached the decision point and began participation in the HIPC Initiative in November of 2008. At that time Togo had an external debt greater than $60 \%$ of its GDP. ${ }^{7}$ Togo reached the completion point in December of 2010 . During the interim period, Togo's "triggers" for reaching the completion point were:

1. preparation of a full $[\mathrm{PRSP}]$ and its satisfactory implementation for at least one year, as evidenced by a PRSP Annual Progress Report [...];

2. maintenance of macroeconomic stability [...];

3. adopt a mechanism to track public expenditures for poverty reduction on the basis of a function expenditure classification $[\ldots]$;

4. appoint judges for the Court of Accounts and give them work space, equipment, and materials; and submit the draft of the Budget Execution Law and draft General Treasury Balance $[\ldots]$ to the Court of Accounts and Parliament for at least one fiscal year;

5. adopt a decree creating the Procurement Regulatory Authority in conformity with the [West African Economic and Monetary Union] Procurement Directives; nominate its managerial staff, and give them an adequate budget $[. .$.$] ;$

6. implement regular public reporting of payments to, and revenues received by, the government for the phosphates sector in line with this aspect of the [Extractive Industry Transparency Initiative] criteria [...];

\footnotetext{
${ }^{6}$ FAQ section: http://web.worldbank.org/WBSITE/EXTERNAL/TOPICS/EXTDEBTDEPT/0,,contentMDK: 20259564 pagePK:64166689 piPK:64166646 theSitePK:469043,00.html\#07 (last accessed May 14, 2015).

${ }^{7}$ http://www.imf.org/external/pubs/ft/scr/2011/cr1128.pdf; p. 38: last accessed May 25, 2015.
} 
7. consolidate external and domestic debt data under a single unit charged with all public debt management tasks;

8. publish an annual report on a government website giving accurate and complete data on external and domestic public debt [...].

These triggers all relate, directly or indirectly, the transparency and quality of governance. Triggers 2 through 8 have elements that are clearly meant to address institutions that relate to a country's accumulation and management of debt. Alternatively, Togo's PRSP was a "comprehensive strategy" based on "four strategic pillars" including the "strengthening of governance" and the "consolidation of the bases for strong and sustained governance". 8 More explicitly, Togo's PRSP referred to the "improvement of political and economic governance"; in particular, "political reforms, strengthening of the rule of law and of the security of persons and property, and implementation of institutional reforms" and "greater transparency in the management of public finance [and] anti-corruption measures". ${ }^{9}$

Undoubtedly, the HIPC Initiative is one of the most comprehensive attempts to provide foreign aid conditional on structural adjustments of the recipient. The Initiative explicitly insists on a participant articulating and pursuing a "national economic development policy" and "an overall integrated national plan" in the form of a PRSP. Has the HIPC Initiative been effective at fostering improvements in institutional quality? Ostensibly, the IMF and World Bank have been taking the conditionality of structural adjustments seriously. Table 4.1 lists the participating countries along with the dates associated with their decision and completion dates; also the number of months spent in the interim period. If the results of participation were simply "rubber-stamped", one might expect fairly uniform participation durations. Quite to the contrary, time spent in the interim period ranged from 3 months (Uganda) to 170 months (Chad), with an average of about 49 months and a comparable standard deviation of about 35 and half months.

\footnotetext{
${ }^{8}$ See IMF Country Report No. 11/28: https://www.imf.org/external/pubs/ft/scr/2011/cr1128.pdf (last accessed May 15, 2015). The triggers are quoted verbatim (with "[...]"s noted).

${ }^{9}$ See "Togo: Poverty Reduction Strategy Paper (2009-11)" (p. https://www.imf.org/external/pubs/ft/scr/2011/cr1128.pdf (last accessed May 15, 2015).
} 
However, the institutional problems that HIPCs face may be more fundamental than any relatively short-term aid/debt relief program can hope to correct. Easterly (2002) points out that the HIPC Initiative countries during 1980-1997 had, on average, worse policies than other low-income countries despite two decades of debt relief efforts prior to the HIPC Initiative. Is this latest program proving more successful?

\subsection{The Record thus Far}

How have HIPCI Initiative participants fared in terms of increasing the quality of their policies and institutions? We use the Fraser Institute's Economic Freedom of the World (EFW) index as a measure of economic institutions (Gwartney et al., 2014) and the Freedom House political rights (PR) index as a measure of political institutions.

The EFW index provides a comprehensive gauge of how well defined property rights are, how free individuals are to make use of their property, and the extent to which individuals are protected from expropriation of their property. ${ }^{10}$ Each country is scoped on a scale of 0 to 10 with 10 representing most economically free. From 2000-2012 the average country has an EFW value of 6.74 and the standard deviation across countries is just about 1 . The PR index measures how freely individuals are allowed to participate in the political process; whether they can vote freely in legitimate elections, join political organizations and parties, and competitively seek public offices. ${ }^{11}$ Each country is scored on a scale of 1 to 7 and its 2000-2012 average and standard deviation are, respectively, 3.37 and 2.16.

\footnotetext{
${ }^{10}$ We use the chain-linked index. The EFW index has been shown to correlate positively with economic growth rates in cross-country samples. For example, see Ayal and Karras (1998), Gwartney et al. (1999), Heckelman and Stroup (2000), and Young and Sheehan (2014). The EFW index has also been shown to correlate positively with political freedom (Lawson and Clark, 2010), health outcomes (Stroup, 2007), labor shares (Young and Lawson, 2014), the extent to which individuals trust one another (Berggren and Jordahl, 2006), and self-reported happiness (Ovaska and Takashima, 2006; Gehring, 2003; Nikolaev, 2014). For a comprehensive review of the literature see Hall and Lawson (2013).

${ }^{11}$ The methodology of the PR index can be found at https://freedomhouse.org/report/freedom-world2012/methodology\#.VWOGRVuA0n0; the PR index data is available at https://freedomhouse.org/reporttypes/freedom-world\#.VWOHz1uA0n0 (both last accessed on May 25, 2015).
} 
Table 4.2 reports (subject to data availability) changes in the EFW and PR indices for HIPC Initiative participants. Changes are reported for, first, the interval from decision point to completion point and, second, the interval from completion point to 5 years later. Changes are reported for individual participants and then, as well, the average changes across participants are reported. Most striking is the number of countries that actually experienced decreases in these institutional measures while participating in the HIPC Initiative. For countries with EFW scores available for both the decision and completion point dates, just about one third (8 out of 25) experienced decreases in measured economic freedom. The record is almost equally dreary for political rights: over $28 \%$ of participants (10 out of 35) experienced decreases in their PR scores while participating in the Initiative.

Averaging over HIPC Initiative participants, the mean EFW change was a mere 0.22. Granted, that is positive; but recall that the standard deviation across countries was just about a full point (0.99 to be exact). Furthermore, 0.22 is less than the 2012 difference between the Democratic Republic of the Congo (4.77) and the Republic of the Congo (4.77). From a different perspective, the 2012 difference between the UK (7.92) and France (7.27) is about three times 0.22 . These are miniscule improvements (if one can call them such) on average. On the political rights front the average HIPC change in the PR index from decision to completion was actually negative $(-0.20)$.

By the design, the HIPC Initiative insists that participants articulate and then have approved a plan for structural adjustment of their policies and institutions (i.e., the PRSP). Consider the case of Cameroon, which entered the HIPC Initiative in October of 2000 and reached completion over 5 years later in April 2006. From decision point to completion point Cameroon experienced decreases in both its EFW score (-0.04) and its PR score (-1.00). However, in 2006 the IMF and World Bank "agreed that Cameroon [had] made sufficient progress and taken the necessary steps to reach its completion point": 
To reach the completion point, Cameroon met a number of triggers involving macroeconomic stability, commitment to a poverty reduction strategy, investment in social services as well as progress in privatization and reform of the forestry and transport sectors. In addition, Cameroon took steps to improve governance and fight official corruption. $^{12}$

Shortly after most of its debt was forgiven, the Cameroon parliament amended the constitution so that Paul Biya could run for a third term as president. President Biya originally came to power in a single-party system in 1982. He was elected to a new seven-year term in 2011 with an implausible $78 \%$ of the vote in an election replete with irregularities. In 2007 , following completion of the HIPC Initiative and the subsequent debt relief, Cameroon's public debt was $12 \%$ of its GDP (down from 51.8\% in 2005). However, by 2014 it had increased to $19.5 \%$ and an IMF report estimated that it would continue to rise to about $30 \%$ during 2015-2019 and then over 50\% during 2020-2034. ${ }^{13}$ This apparently corresponds to results of reforms deemed "sufficient progress" by the World Bank and IMF.

Generally, one may argue that short-run participation in the HIPC Initiative merely laid the foundations for subsequent, meaningful reforms. However, participants did not generally experience large gains in EFW and PR scores during the 5 years subsequent to completion of the Initiative. The average EFW score increase was only 0.33 for countries for which we have the data. (The average increase was only 0.26 if the Rwanda outlier is excluded.) The average PR score increase was a bit better (0.44) but $24 \%$ (6 out of 25 ) of countries experienced actual decreases in their measured political rights in the 5 years subsequent to participation.

Of course, the changes reported in table 4.2 are entirely unconditional. In table 4.3 we report some results based on regressing changes in institutional quality scores on HIPC Initiative aid disbursements. For each institutional measure (EFW or PR) we first consider

\footnotetext{
${ }^{13}$ https://www.imf.org/external/pubs/ft/dsa/pdf/2012/dsacr12237.pdf; table 1, p. 2: last accessed May 26, 2015. http://www.imf.org/external/pubs/ft/scr/2014/cr14212.pdf; table 7, p. 6: last accessed May 26, 2015.
} 
regressions including (a) the total amount of debt relief disbursed and then (b) that total separated into (a) the amount provided in the interim (decision to completion) period and the remainder provided subsequent to completion. ${ }^{14}$ In each of the (a) and (b) regressions we control for a participant's initial (decision point) institutional score and the months spent by the participant in the interim period. Then for each institutional measure we also report a regression where (c) we additionally control for a country's real per capita GDP growth rate during the interim period, a dummy variable for the African continent, and the ethnic fractionalization measure provided by Alesina et al. (2003). Even in the case of the (c) regressions the control variable set is very limited. We only have between 25 and 35 observations per regression to work with and make no claims whatsoever in terms of identifying "true" causal effects. Rather, the point of table 4.3 is simply to report the partial correlations of aid with institutional change while taking into account some other basic covariates.

Total aid does not enter into either of the (a) regressions significantly. The point estimates on total HICP Initiative aid are also very small. A 10\% increase in a country's total aid is associated with about a 0.66 point increase in its $\mathrm{PR}$ score, and only about a 0.02 increase in its EFW score. Even if these estimated correlations were statistically different than zero (which they are not) they suggest that the HIPC Initiative is not resulting in meaningful reforms of policies and institutions on the part of its participants.

The story remains essentially the same looking at the (b) and (c) regressions. Splitting the HIPC aid into interim and upon-completion components may make sense if HIPC Initiative if the interim period is the "carrot" provide the incentives for reforms that ultimately lead to the big debt relief upon completion. The coefficient point estimates are often consistent with this. (Except for in the PR regression (b), interim aid enters positively while the remainder enters negatively.) But all of the coefficient estimates are small; none are

\footnotetext{
${ }^{14}$ These disbursements are gathered from the HIPC Status of Implementation Reports for individual countries. Aid disbursements are taken as decision point GDP shares and then logged before entering the regressions. We lose handful of observations because GDP numbers are not available for Guyana, Haiti, and Nicaragua. The primary result (i.e., aid variables to not enter significantly and with quantitatively small point estimates) is unchanged if aid is not taken as a share of GDP. GDP data is from the Penn World Table 8.1 (Freenstra et al., 2015).
} 
statistically significant.

\subsection{Conclusion}

Overall, the record of the HIPC Initiative is troubling. The good news is that none of the results reported above link the Initiative to decreases in institutional quality. But the HIPC Initiative is a comprehensive, structured attempt by the IMF and World Bank to provide foreign aid - specifically debt relief - conditional on participants making policy and institutional reforms. What is troubling is the lack of any evidence that this conditionality has been effective.

Also troubling is the fact that the IMF and World Bank signed off on participants' completion points as if meaningful reforms had occurred. We highlight the case of Cameroon. Cameroon experienced measured decreases in measured economic and political institutional quality while participating in the HIPC Initiative. The IMF and World Bank stated that Cameroon "had made significant progress and taken the necessary steps"; including "steps to improve governance and fight corruption". Almost a decade later, Cameroon has seen its debt level rise again under the leadership of the same corrupt president that it has had since 1982.

The political economy concerns associated with foreign aid are compelling. Yet despite mounting evidence that aid is not effective even in good policy and institutional environments, and that aid actually leads, all else equal, to decreases in the quality of policies and institutions, calls for increased foreign aid persist. These include calls for more debt relief, such as that provided by the HIPC Initiative. Unfortunately, the record of HIPC Initiative not only serves to emphasize the importance of political economy concerns. Its record suggests that even foreign aid programs designed in recognition of the political economy concerns to address them are still unlikely to succeed. 


\subsection{Tables}

Table 4.1: HIPC Initiative Participants: Decision and Completion Dates

\begin{tabular}{|c|c|c|c|}
\hline Country & Decision Date & Completion Date & Interim (Months) \\
\hline Afghanistan & July 2007 & January 2010 & 30 \\
\hline Benin & July 2000 & March 2003 & 32 \\
\hline Bolivia & February 2000 & June 2001 & 16 \\
\hline Burkina Faso & July 2000 & April 2002 & 21 \\
\hline Burundi & August 2005 & June 2009 & 41 \\
\hline Cameroon & October 2000 & July 2010 & 67 \\
\hline Central African Republic & September 2007 & June 2009 & 21 \\
\hline Chad & May 2001 & May 2015 & 170 \\
\hline Comoros & June 2010 & December 2012 & 30 \\
\hline Congo, Dem. Rep. of the & July 2003 & July 2010 & 84 \\
\hline Congo, Rep. of & March 2006 & January 2010 & 46 \\
\hline Cote d'Ivoire & March 2009 & June 2012 & 40 \\
\hline Ethiopia & November 2001 & April 2004 & 29 \\
\hline Gambia, The & December 2000 & December 2007 & 84 \\
\hline Ghana & February 2002 & July 2004 & 29 \\
\hline Guinea & December 2000 & September 2012 & 143 \\
\hline Guinea-Bissau & December 2000 & December 2010 & 120 \\
\hline Guyana & November 2000 & December 2003 & 37 \\
\hline Haiti & November 2006 & June 2009 & 31 \\
\hline Honduras & June 2000 & April 2005 & 58 \\
\hline Liberia & March 2008 & June 2010 & 27 \\
\hline Madagascar & December 2000 & October 2004 & 46 \\
\hline Malawi & December 2000 & August 2006 & 68 \\
\hline Mali & September 2000 & March 2003 & 30 \\
\hline Mauritania & February 2000 & June 2002 & 28 \\
\hline Mozambique & April 2000 & September 2001 & 17 \\
\hline Nicaragua & December 2000 & January 2004 & 37 \\
\hline Niger & December 2000 & April 2004 & 40 \\
\hline Rwanda & December 2000 & April 2005 & 52 \\
\hline Sao Tome and Principe & December 2000 & March 2007 & 75 \\
\hline Senegal & June 2000 & April 2004 & 46 \\
\hline Sierra Leone & March 2002 & December 2006 & 57 \\
\hline Tanzania & April 2000 & November 2001 & 19 \\
\hline Togo & November 2008 & December 2010 & 25 \\
\hline Uganda & February 2000 & May 2000 & 3 \\
\hline Zambia & December 2000 & April 2005 & 52 \\
\hline
\end{tabular}

Source: various IMF HIPC Initiative reports. 
Table 4.2: HIPC Initiative Participants: Changes in Economic Freedom and Political Rights

\begin{tabular}{|c|c|c|c|c|}
\hline \multirow[t]{2}{*}{ Country } & \multicolumn{2}{|c|}{ Change in EFW } & \multicolumn{2}{|c|}{ Change in PR } \\
\hline & $\begin{array}{l}\text { (Decision to } \\
\text { Completion) }\end{array}$ & $\begin{array}{c}(\text { Next } \\
5 \text { Years })\end{array}$ & $\begin{array}{l}\text { (Decision to } \\
\text { Completion) }\end{array}$ & $\begin{array}{c}(\text { Next } \\
5 \text { Years })\end{array}$ \\
\hline Afghanistan & & & -1 & \\
\hline Benin & 0.49 & 0.05 & 0 & 0 \\
\hline Bolivia & -0.27 & -0.27 & 0 & 2 \\
\hline Burkina Faso & & & 0 & 1 \\
\hline Burundi & 0.4 & & 1 & 2 \\
\hline Cameroon & -0.04 & 0.09 & -1 & 0 \\
\hline $\begin{array}{l}\text { Central African Republic } \\
\text { Chad }\end{array}$ & 0.14 & & 0 & 2 \\
\hline Comoros & & & 0 & \\
\hline Congo, Dem. Rep. of the & 0.4 & & 0 & \\
\hline Congo, Rep. of & 0.16 & & 1 & \\
\hline Cote d'Ivoire & -0.01 & & -1 & \\
\hline Ethiopia & & & 0 & 0 \\
\hline Gambia, The & & & -3 & 2 \\
\hline Ghana & 0.35 & 0.35 & 0 & -1 \\
\hline Guinea & & & -1 & \\
\hline Guinea-Bissau & 1.02 & & 0 & \\
\hline Guyana & -0.45 & 0.17 & 0 & 0 \\
\hline Haiti & 0.24 & & 0 & \\
\hline Honduras & 0.39 & 0.19 & 0 & 1 \\
\hline Liberia & & & 0 & \\
\hline Madagascar & 0.91 & 0.4 & 1 & 3 \\
\hline Malawi & 0.57 & 0.68 & 1 & -1 \\
\hline Mali & -0.1 & -0.06 & 0 & 0 \\
\hline Mauritania & & & -1 & -1 \\
\hline Mozambique & & & 0 & 0 \\
\hline Nicaragua & 0.21 & 0.22 & 0 & 1 \\
\hline Niger & -0.17 & 0.49 & -1 & 2 \\
\hline Rwanda & 0.52 & 1.54 & -1 & 0 \\
\hline Sao Tome and Principe & & & 1 & 0 \\
\hline Senegal & -0.07 & 0.37 & -1 & 1 \\
\hline Sierra Leone & 0.46 & 0.63 & 0 & -1 \\
\hline Tanzania & 0.07 & 0.33 & 0 & 0 \\
\hline Togo & 0.34 & & 0 & \\
\hline Uganda & 0 & 0.04 & 0 & -1 \\
\hline Zambia & -0.04 & 0.34 & -1 & -1 \\
\hline HIPC Avg. Change & 0.22 & 0.33 & -0.2 & 0.44 \\
\hline
\end{tabular}


Table 4.3: Relationship between Aid and Changes in Economic Freedom during Participation in HIPC Initiative

\begin{tabular}{|c|c|c|c|c|c|c|}
\hline & \multicolumn{3}{|c|}{ Change in EFW } & \multicolumn{3}{|c|}{ Change in PR } \\
\hline & (a) & (b) & (c) & (a) & (b) & (c) \\
\hline (log) Total Aid & $\begin{array}{c}0.0024 \\
(0.0090)\end{array}$ & & & $\begin{array}{c}0.0656 \\
(0.1178)\end{array}$ & & \\
\hline$(\log )$ Interim Aid & & $\begin{array}{c}0.0249 \\
(0.1046)\end{array}$ & $\begin{array}{c}0.0185 \\
(0.1230)\end{array}$ & & $\begin{array}{c}0.0308 \\
(0.2103)\end{array}$ & $\begin{array}{c}0.0219 \\
(0.3129)\end{array}$ \\
\hline$(\log )$ (Total Net of Interim) & & $\begin{array}{c}-0.0237 \\
(0.0610)\end{array}$ & $\begin{array}{c}-0.0353 \\
(0.0651)\end{array}$ & & $\begin{array}{c}0.0293 \\
(0.1658)\end{array}$ & $\begin{array}{c}-0.0139 \\
(0.2220)\end{array}$ \\
\hline Initial EFW or PR & $\begin{array}{c}-0.2133^{* *} \\
(0.0938)\end{array}$ & $\begin{array}{c}-0.2197^{* *} \\
(0.1012)\end{array}$ & $\begin{array}{l}-0.2152 \\
(0.1267)\end{array}$ & $\begin{array}{c}-0.2696^{* * *} \\
(0.0811)\end{array}$ & $\begin{array}{c}-0.2726^{* * *} \\
(0.0920)\end{array}$ & $\begin{array}{c}-0.2990^{* * *} \\
(0.1035)\end{array}$ \\
\hline Months to Completion & $\begin{array}{c}0.0041 \\
(0.0030)\end{array}$ & $\begin{array}{c}0.0045 \\
(0.0030)\end{array}$ & $\begin{array}{c}0.0047 \\
(0.0032)\end{array}$ & $\begin{array}{c}-0.002 \\
(0.0030)\end{array}$ & $\begin{array}{l}-0.0025 \\
(0.0048)\end{array}$ & $\begin{array}{l}-0.0025 \\
(0.0066)\end{array}$ \\
\hline Per Capita GDP Growth & & & $\begin{array}{c}0.0928 \\
(0.6362)\end{array}$ & & & $\begin{array}{c}0.6939 \\
(1.3340)\end{array}$ \\
\hline Africa & & & $\begin{array}{c}0.0029 \\
(0.2902)\end{array}$ & & & $\begin{array}{c}0.5063 \\
(0.7504)\end{array}$ \\
\hline Ethnic Fractionalization & & & $\begin{array}{l}-0.2445 \\
(0.2835)\end{array}$ & & & $\begin{array}{l}-0.0343 \\
(0.9249)\end{array}$ \\
\hline $\mathrm{R} 2$ & 0.4899 & 0.4933 & 0.5248 & 0.3691 & 0.3697 & 0.3521 \\
\hline Observations & 22 & 22 & 22 & 31 & 31 & 29 \\
\hline
\end{tabular}

Notes: ${ }^{*},{ }^{* *}$, and ${ }^{* * *}$ denote statistical significance the 10,5 , and 1 percent levels, respectively.

White standard errors are reported in parentheses.

Constants are included in all regressions (though not reported).

EFW is the Fraser Institute's Economic Freedom of the World index;

$\mathrm{PR}$ is the Freedom House political rights index. 


\section{Chapter 5}

\section{Conclusion}

This dissertation is an attempt to study the effectiveness of the Heavily Indebted Poor Countries (HIPC) Initiative and the Multilateral Debt Relief Initiative (MDRI). For the first essay, I employ a survival time model to perform a duration analysis on the time it takes a member country to go from the Decision Point to the Completion Point. In the second essay, I use the Spatial Durbin Model (SDM) to check for spillover effects. And the final essay examines the change in institutional quality of HIPC member countries from the time they join the program to the time that they complete it.

Results from the first essay show no evidence of moral hazard. Using the Cox proportional hazard model, I find that interim aid does not help in shortening the length of time that countries take to go from the Decision Point to the Completion Point. In addition, high corruption thwarts their process of completing all of the requirements. Lower institutional quality, such as lower rule of law, also prolong the interim duration. However, since the interaction terms between interim debt relief and institutional value are statistically insignificant, I do not conclude that there is moral hazard.

The second essay studies the spatial spillover effects of HIPC aid, membership, and length of time in the program on real GDP per capita. My analysis yields negative results for all three measures. HIPC debt relief amount and the interim period have negative direct effects on real GDP per capita. Suggesting that their impacts are contained within the recipient 
country. However, HIPC membership has statistically significant indirect effect. This translates to spatial spillovers. When a country joins the HIPC Initiative, there is a potential that it could harm the neighboring countries' real GDP per capita.

The final essay reviews the HIPC Initiative accomplishments, or lack thereof, on institutional quality. The initiative set institutional reform as one of the crucial trigger point for reaching the Completion Point; hence, it makes sense for us to look for a positive change in institutional quality after the member country exits the program. We use the Fraser Institute's Economic Freedom of the World index to measure economic institutions and the Freedom House political rights index as a measure for political institutions. We find no evidence of improved institutional quality in any aspect.

Overall, the findings suggest that being a member of the HIPC Initiative does not yield many positive outcomes. The interim debt relief does not shorten the interim duration. There are negative effects of being a HIPC member on real GDP per capita, and the effects spillover to neighboring countries. Furthermore, the condition of structural reform to complete the HIPC program does not seem to produce institutional changes. These results imply that the Initiative is not monitoring these countries closely enough. The Initiative should implement a stricter policy that would force member countries to do more to lift up their economic and political quality. As institutional quality increases, it contribute towards reducing interim duration and raising standard of living in HIPC members. 


\section{References}

Acemoglu, D., Johnson, S., 2005. Unbundling institutions. Journal of Political Economy 113, 949-1004.

Acemoglu, D., Johnson, S., Robinson, J., 2001. The origins of comparative development: an empirical investigation. American Economic Review 91, 1369-1401.

Acemoglu, D., Johnson, S., Robinson, J., 2002. Reversal of fortune: geography and institutions in the making of the modern world income distribution. Quarterly Journal of Economics 117, 1231-1294.

Alesina, A., Devleeschauwer, A., Easterly, W., Kurlat, S., Wacziarg, R., 2003. Fractionalization. Journal of Economic Growth 8, 155-194.

Anselin, L. (1988) Spatial Econometrics: Methods and Models, Dordrecht, Kluwer.

Atsu Amegashie, J. Bazoumana Ouattara, and Eric Strobl (2007). "Moral Hazard and the Composition of Transfers: Theory with an Application to Foreign Aid." CESifo Working Paper No. 1996. Category 1: Public Finance.

Auty, R. M., 1990 Resource-Based Industrialization: Sowing the Oil in Eight Developing Countries. Oxford University Press, New York.

Ayal, E.B., Karras, G., 1998. Components of economic freedom and growth: an empirical study. Journal of Developing Areas 32, 327-338.

Barro, R., 1996. Democracy and growth. Journal of Economic Growth 1, 1-27.

Bauer, P. T., 1969. Dissent on Development. Scottish Journal of Political Economy 16, 75-94.

Bauer, P. T., 1972. Dissent on Development. Harvard University Press, Cambridge.

Baumol, W. J., 1990. Entrepreneurship: productive, unproductive, and destructive. Journal of Political Economy 98, 893-921. 
Berggren, N., Jordahl, H., 2006. Free to trust: economic freedom and social capital. Kyklos $59,141-169$.

Bivand, R, and Piras, G (2015). Comparing Implementations of Estimation Methods for Spatial Econometrics. Journal of Statistical Software, 63(18), 1-36. URL http://www. jstatsoft.org/v63/i18/.

Bivand, R. S., Hauke, J., and Kossowski, T. (2013). Computing the Jacobian in Gaussian spatial autoregressive models: An illustrated comparison of available methods. Geographical Analysis, 45(2), 150-179.

Boone, P., 1996. Politics and the effectiveness of foreign aid. European Economic Review 40, 289-329.

Borzenstein, Eduardo. (1990). "Debt Overhang, Debt Reduction and Investment: The Case of the Philippines." IMF Working Paper 90/77.

Brambor, T., Clark, W. R., Golder, M. 2006. Understanding Interaction Models: Improving Empirical Analyses. Political Analysis 14, 63-82.

Brennan, G., Buchanan, J. 1980. The Power to Tax: Analytical Foundations of a Fiscal Constitution. Cambridge University Press, Cambridge.

Bruce, Donald, Karie Barbour, and Angela Thacker (2004). Welfare Program Reentry among Postreform Leavers. Southern Economic Journal. 70 (4): 816-836.

Brumm, H. J., 2003. Aid, policies, and growth: Bauer was right. Cato Journal 23, 167-174.

Brautigam, D. A., Knack, S., 2004. Foreign aid, institutions, and governance in Sub-Saharan Africa. Economic Development and Cultural Change. 52, 255-285.

Burnside, C., Dollar, D., 2000. Aid, policies, and growth. American Economic Review 90, 847-868.

Burnside, C., Dollar, D., 2004. World Bank Policy Research Paper O-2834.

Burnside, Craig and Dollar, David (2000). "Aid, Policies, and Growth." American Economic Review. 90 (4): 847-868.

Burnside, Craig and Dollar, David (2000). Aid, Policies, and Growth, American Economic Review. 90 (4): 847-868.

Calmette, Marie-Franoise and Kilkenny, Maureen (2001). "International Charity under Asymmetric Information." Economics Letters, 74 (1). pp. 107-111. 
Cassimon, D., van Campenhout, B., 2007. Aid effectiveness, debt relief and public finance response: evidence from a panel of HIPC countries. Review of World Economies/ Weltwirtschaftliches Archiv 143, 742-763.

Cecchetti, S., Mohanty, M., and Zampolli, F. 2011. "The Real Effects of Debt." Presented at the "Achieving Maximum Long-Run Growth" symposium sponsored by the Federal Reserve Bank of Kansas City, Jackson Hole, Wyoming, 25-27 August 2011.

Chervin, Michael and van Wijnbergen, Sweder (2010). "Economic Growth and the Volatility of Foreign Aid." working paper.

Claessens, Stijn. (1990). "The Debt Laffer Curve: Some Estimates." World Development, Vol. 18.

Cohen, Daniel. (1997). "Growth and External Debt: A New Perspective on the African and Latin American Tragedies." CEPR Discussion Paper 1753.

Dagdeviren , H and Weeks, J 2001 "How much poverty could HIPC reduce" Business School Working Papers, vol. UHBS 2001-7, Economics Paper, vol. 25, University of Hertfordshire.

Djankov, S., Montalvo, J. G., Reynal-Querol, M., 2008. The curse of aid. Journal of Economic Growth 13, 169-194.

Dooley, Michael P. (1989). "Debt Relief and Leveraged Buy-Outs." International Economic Review. 30 (1): 71-75

Doucouliagos, H., Paldam, M., 2008. Aid effectiveness on growth: a meta-analysis. European Journal of Political Economy 24, 1-24.

Doucouliagos, H., Paldam, M., 2009. Conditional aid effectiveness: a meta-analysis. Journal of International Development 21, 1582-1601.

Douglas, Stratford. (1998). "The Duration of the Smoking Habit." Economic Inquiry. 36: 49-64.

Easterly, W., 2002. How did heavily indebted poor countries become heavily indebted? Reviewing two decades of debt relief. World Development 20, 1677-1696.

Easterly, W., 2003. Can foreign aid buy growth? Journal of Economic Perspectives 17, $23-48$.

Easterly, W., Levine, R., Roodman, D., 2000. New data, new doubts: a comment on Burn- 
side and Dollar's 'aid policies and growth' (2000). American Economic Review 94, 774-780. Easterly, William. (2002). "How Did Heavily Indebted Poor Countries Become Heavily Indebted? Reviewing Two Decades of Debt Relief." World Development. 1327.

Elbadawi, Ibrahim A., Benno J. Ndulu and Njuguna Ndung'u. (1996). "Debt Overhang and Economic Growth in Sub-Sahara Africa." Paper present at IMF and World Bank Conference on External Financing for Low-Income Countries, Washington, DC.

Elhorst J. Paul (2010): Applied Spatial Econometrics: Raising the Bar, Spatial Economic Analysis, 5:1, 9-28

Feenstra, R. C., Inklaar, R., Timmer, M. P., 2015. The next generation of the Penn World Table. American Economic Review (forthcoming): www.ggdc.net/pwt.

Florax, R.J.G.M., Folmer, H. and Rey, S.J. (2003). "Specification searches in spatial econometrics: the relevance of Hendry's methodology, Regional Science and urban Economics", $33,557-579$.

Fonchamnyo, Dobdinga C. (2009). "Debt Relief Incentives in Highly Indebted Poor Countries (HIPC): An Empirical Assessment." International Advances in Economic Research, 15 (3). 322-335.

Fogarty, Brian J., Farida Jalalzai, and Chad A. Hankinson. (2013). "A duration analysis of congressional widow's careers." The Social Science Journal, 50: 299-305.

Gallup, John, Jeffrey Sachs and Andrew Mellinger. (1999). "Geography and Economic Development." International Regional Science Review 22(2): 179-232.

Gehring, K., 2013. Who benefits from economic freedom? unraveling the effect of economic freedom on subjective well-being. World Development 50, 74-90.

Gibbons, Stephen and Henry G. Overman. 2012. "Mostly Pointless Spatial Econometrics?" Journal of Regional Science, 52(2), 172-191.

Gwartney, J., Lawson, R., and Holcombe, R. 1999. "Economic Freedom and the Environment for Economic Growth." Journal of Institutional and Theoretical Economics 155, 643-663.

Gwartney, J., Lawson, R., Hall, J., 2014. Economic Freedom of the World: 2014 Annual Report. Fraser Institute, Vancouver.

Hall, J. C., Lawson, R. A., 2013. Economic freedom of the world: an accounting of the 
literature. Contemporary Economic Policy 32, 1-19.

Hall, R. E., Jones, C. I., 1999. Why do some countries produce so much more output per worker than others? Quarterly Journal of Economics 114, 83-116.

Heckelman, J. C., Knack, S., 2008. Foreign aid and market-liberalizing reform. Economica $75,524-548$.

Heckelman, J. C., Stroup, M. D., 2000. Which economic freedoms contribute to growth? Kyklos 53, 527-544.

Heller, Peter S., and Sanjeev Gupta. (2002). "Challenges in Expanding Development Assistance." IMF Policy Discussion Paper 02/5. Washington, D.C.: International Monetary Fund.

Hlavac, Marek (2014). stargazer: LaTeX/HTML code and ASCII text for well-formatted regression and summary statistics tables. R package version 5.1. http://CRAN.R-project.org/ package $=$ stargazer

Hosseini, H.M. and Kaneko, Shinji (2012). "Spatial Spillover of Governance and Institutional Quality: A Spatial Econometric Approach." Development Discussion Policy Paper. IDA \& IMF, 2013. Heavily indebted poor countries (HIPC) Initiative and Multilateral Debt Relief Initaitive (MDRI) - Statistical Update. (http://siteresources.worldbank.org/ INTDEBTDEPT/ProgressReports/23395262/HIPCSta tisticalUpdate2013.pdf).

Isopi, Alessia and Fabrizio Mattesini. "Good Donors or Good Recipients? A Repeated Moral Hazard Model of Aid Allocation." CREDIT Research Paper.

Jeanne, O., Zettelmeyer, J., Bacchetta P., and Scott, A. "International Bailouts, Moral Hazard and Conditionality." 2001. Economic Policy. Vol. 16, No. 33 pp. 407-432.

Jensen, Christa D. and Lacombe, Donald J. (2012). "A Note on Partitioning Effects Estimates Over Space." Letters in Spatial and Resource Sciences.

Kalyvitis, S., Vlachaki, I., 2012. When does more aid imply less democracy? an empirical examination. European Journal of Political Economy 28, 132-146.

Kelejian, Harry, Murrell, Peter, Shepotylo, Oleksandr (2008). Spatial Spillovers in the Development of Insititutions. Working Paper.

Kluver, Heike and Sagarzazu, Inaki (2013). Ideological congruency and decision-making speed: The effect of partisanship across European Union institutions. European Union Pol- 
itics. 14(3): 388-407.

Knack, S., Keefer, P., 1995. Institutions and economic performance: cross-country tests using alternative measures. Economics and Politics 7, 207-227.

Koeda, Junko. 2008. "A Debt Overhang Model for Low-Income Countries." IMF Staff Papers, Vol. 55, Issue 4, pp. 654-678.

Krugman, Paul. (1988). "Financing Versus Forgiving a Debt Overhang." NBER Working Paper 2486.

Kumar, M. and Woo, J. 2010. "Public Debt and Growth." IMF Working Paper WP/10/174. July.

La Porta, R., Lopez-de-Silanes, F., Shleifer, A.. and Vishny, R. 1999. The Quality of Government. Journal of Law, Economics and Organization, 15(1): 222-279.

Lacombe, Donald J. (2004). "Does Econometric Methodology Matter? An Analysis of Public Policy Using Spatial Econometric Techniques." Geographical Analysis, Vol. 36, No. 2, April 2004, pp. 105-108.

Lawson, R. A., Clark, J. R., 2010. Examining the Hayek-Friedman hypothesis on economic and political freedom. Journal of Economic Behavior and Organization 74, 230-239.

Leeson, P. T., 2008., Escaping poverty: foreign aid, private property, and economic development. Journal of Private Enterprise 23, 39-64.

LeSage, J. P. and Pace, R. K. (2009) Introduction to Spatial Econometrics, Boca Raton, Taylor and Francis.

Marshall, G. M., Gurr, T. R., Jaggars. 2011. Polity IV Project: Political Regime Characteristics and Transitions, 1800-2008.http://www.systemicpeace.org/polity/polity4.htm. Murdoch, J.C. and T. Sandler (2002). "Economic Growth, Civil Wars and Spatial Spillovers," Journal of Conflict Resolution, vol. 46(1), pp. 91-110.

Myrdal, G., 1956. Development and Underdevelopment. National Bank of Egypt, Cairo. Ndikumana, L. (2004). "Additionality of debt relief and debt forgiveness, and implications for future volumes of official assistance." International Review of Economics and Finance, 13 (3), pp. 325-340.

Nikolaev, B., 2014. Economic freedom \& subjective well-being-revisiting the relationship. Working Paper (http://borisnikolaev.com/wp-content/uploads/2014/05/FREE-SW_Bfinal.pdf). 
North, D. C., 1990. Institutions, Institutional Change and Economic Performance. Cambridge University Press, Cambridge.

North, D. C., Thomas, R. P., 1973. The Rise of the Western World: A New Economic History. Cambridge University Press, Cambridge.

North, Douglass (1990). Institutions, Institutional Change and Economic Performance, Cambridge: Cambridge University Press.

Nwachukwu, J. "The Prospects for Foreign Debt Sustainability in Post-Completion-Point Countries: Implications of the HIPC-MDRI Framework." (2008) Development Policy Review, 26 (2): 171-188.

Ovaska, T., Takashima, R., 2006. Economic policy and the level of self-perceived well-being: an international comparison. Journal of Socio-Economics 35, 308-325.

Pedersen, K. R. (2001) "The Samaritan Dilemma and the Effectiveness of Development Aid." International Tax and Public Finance, 8, 693- 703.

Powell, B., Ryan, M., 2006. Does development aid lead to economic freedom? Journal of Private Enterprise 22, 1-21.

Ragusa, Jordan Michael (2010). The lifecycle of public policy: An event history analysis of repeals to landmark legislative enactments, 1951-2006. American Politics Research 38(6): 1015-1051.

Rajan, R., Subramanian, A., 2007. Does aid affect governance? American Economic Review 97, 322-327.

Rajan, R., Subramanian, A., 2008. Aid and growth: what does the cross-country evidence really show? Review of Economics and Statistics 90, 643-655.

Reinhart, Carmen M., Vincent R. Reinhart, and Kenneth S. Rogoff. 2012. "Public Debt Overhangs: Advanced-Economy Episodes since 1800." Journal of Economic Perspectives, 26(3): 69-86.

Rodrick, D. A., Subramanian, A., Trebbi, F., 2004. Institutions rule: the primacy of institutions over geography and integration in economic development. Journal of Economic Growth 9, 131-165.

Rostow, W. W., 1990 Theorists of Economic Growth from David Hume to the Present. Oxford University Press, Oxford. 
Sachs, J., Warner, A., 1999. The big push, natural resource booms and growth. Journal of Development Economics 59, 43-76.

Sachs, J., Warner, A., 2001. The curse of natural resources. European Economic Review 45, 827-838.

Sachs, Jeffrey. (1989). "The Debt Overhang of Developing Countries." In Debt Stabilization and Development: Essays in Memory of Carlos Diaz-Alejandro. Eds. Guillermo A. Calvo, Ronald Findlay, Pentti Kouri, and JorgeBraga de Macedo. Oxford and Cambridge, MA: Blackwell, 1989, pp. 80-102.

Sachs, Jeffrey. (2002). "Resolving the Debt Crisis of Low Income Countries." Brookings Papers on Economic Activity, 1:2002.

Shepotylo, Oleksandr (2010). "Spatial complementarity of FDI: example of transition countries." Discussion Paper 29.

Stroup, M. D., 2007. Economic freedom, democracy, and the quality of life. World Development 35, 52-66.

Svensson, J., 2000. Foreign aid and rent-seeking. Journal of International Economics 51, 437-461.

Svensson, Jakob. (2000). "When is foreign aid policy credible? Aid dependence and conditionality," Journal of Development Economics, Elsevier, vol. 61(1), pp. 61-84.

Teorell, Jan, Nicholas Charron, Stefan Dahlberg, Soren Holmberg, Bo Rothstein, Petrus Sundin and Richard Svensson. 2013. The Quality of Government Dataset, version 20Dec13. University of Gothenburg: The Quality of Government Institute, http://www.qog.pol.gu.se. Therneau, T (2015). A Package for Survival Analysis in S. version 2.38, http://CRAN.Rproject.org $/$ package $=$ survival.

Therneau, T and Patricia M. Grambsch (2000). Modeling Survival Data: Extending the Cox Model. Springer, New York. ISBN 0-387-98784-3.

Vega, Solmaria Halleck and J. Paul Elhorst. 2015. Journal of Regional Science, vol. 00, No. 0: $1-25$.

Williamson, C. R., 2010. Exploring the failure of foreign aid: the role of incentives and information. Review of Austrian Economics 23, 17-33.

Young, A. T., Lawson, R. A., 2014. Capitalism and labor shares: a cross-country panel 
study. European Journal of Political Economy 33, 20-36.

Young, A. T., Sheehan, K. M.,, 2014. Foreign aid, institutional quality, and growth. European Journal of Political Economy 36, 195-208. 